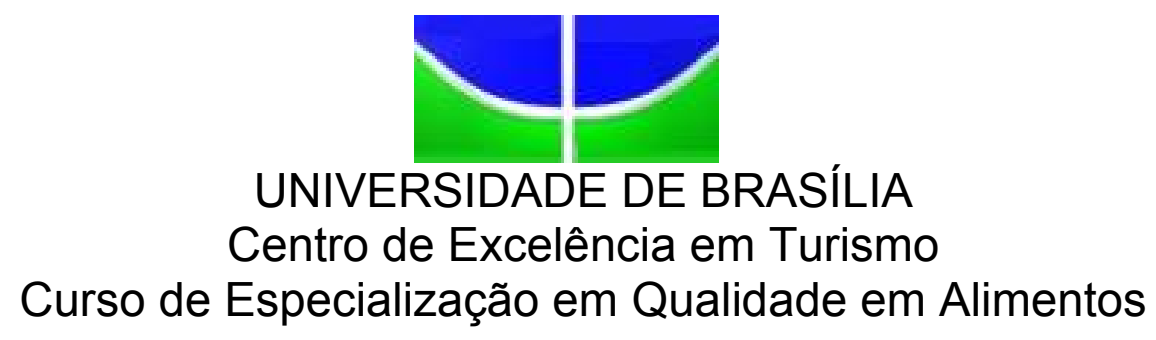

\title{
ANÁLISE E DEFINIÇÃO DE CARDÁPIOS DE SELF- SERVICE SEGUNDO OS ASPECTOS TOXICOLÓGICOS E DIETÉTICOS DOS ALIMENTOS PARA COLETIVIDADE SADIA
}

Daniela Guimarães Moura

Raquel Assunção Botelho, mestre em Ciência dos Alimentos.

Brasília, DF, Janeiro de 2003. 
Moura, Daniela G.

Análise e definição de cardápios de self-service segundo os aspectos toxicológicos e dietéticos dos alimentos para coletividade sadial Daniela G. Moura.

$52 \mathrm{p}$.

Monografia (especialização) - Universidade de Brasília.

Centro de Excelência em Turismo. Brasília, 2003.

Área de concentração: Nutrição

Orientadora: Raquel Assunção Botelho.

1.Self-service.2. Cardápios.3. Técnica dietética e toxicologia dos alimentos.4. Saúde da população. - Monografia 


\section{Resumo}

Alimentar-se envolve muito mais do que necessidades orgânicas, onde vários fatores como a família, comunidade, padrões culturais, tradição, crenças e tabus a influenciam. O ato de comer é muito abrangente na vida do indivíduo, por isso a refeição deve ser prazerosa. Diante de um cotidiano agitado, a humanidade passou a não ter tempo suficiente para almoçar em casa, optando por self-service próximos ao trabalho. Com o intuito de manter e promover a saúde e bem-estar da população foi realizado um trabalho no Restaurante Self-service do Grupo Coral, onde se analisaram os cardápios pré-existentes de 8 semanas, quanto às técnicas de preparo e riscos de toxicidade. Neste contexto, o profissional de nutrição deve ser eficiente e abrangente, criando novas preparações, ou desenvolvendo cardápios menos repetitivos. Dentro deste espectro, foi possível verificar os princípios de elaboração de um cardápio e apontar os alimentos que possuíam agentes tóxicos à saúde. Foram estudados aqueles presentes naturalmente: os glicosídeos cianogênicos, glicosinolatos, glicoalcalóides, nitratos; os advindos do processamento: produtos da oxidação lipídica, hidorcarbonetos aromáticos policíclicos, as aminas aromáticas heterocíclicas, os produtos da reação de Maillard e, ainda, os fatores antinutricionais, como os oxalatos, fitatos e taninos. Concluiu-se que a população deve ser informada dos efeitos tóxicos, carcinogênicos, mutagênicos destas substâncias para ter o cuidado de variar a sua refeição. Constatou-se que, diante do cardápio oferecido no Restaurante estudado, é possível que o cliente faça uma alimentação balanceada suprindo suas necessidade de nutrientes, reduzindo o risco de toxicidade à sua saúde.

Palavras-chave: Self-service, cardápios, técnica dietética, toxicologia, saúde da população. 


\begin{abstract}
The need to be fed involves much more than organic needs; it includes factors like family, community, cultural patterns, belief and taboos. The act of eating is wider in life and in the personality of the human being, that's why the meals must be pleasurable. With history evolution and facing the agitated day-by-day, men don't have as much time to have lunch at home in a family environment. Now, they choose for self-services near their jobs. In this context, problems arise in relation to people's heath. This study was developed to initiate a program to promote health and wellbeing in a self-service restaurant. Eight previous menus of the restaurant were evaluated for toxicity risks and preparation techniques. The nutritionist must be efficient and prepared to create new preparations and develops less repetitive menus, with greater variety of ingredients and techniques. It was possible to determine principles of menu planning like: color, shape, taste, texture, ingredients, seasoning and preparation form. It was also possible to evaluate the toxic agents for health. The toxic agents present in food evaluated were: cianogenic glycosides, glycosinolates, glycoalcaloydes, and nitrates. And the toxic agents from the food processing were: lipid oxidation products, hydrocarbonate, aromatic amines, Maillard reaction products and antinutritional factors like oxalates, phytates and tannins. It is concludes that it is possible for clients to have a balanced meal, reducing the toxicological risk for the health. Also, the client should be alerted of the carcinogenic and mutagenic effects of these substances presented in the diet.
\end{abstract}


SUMÁRIO

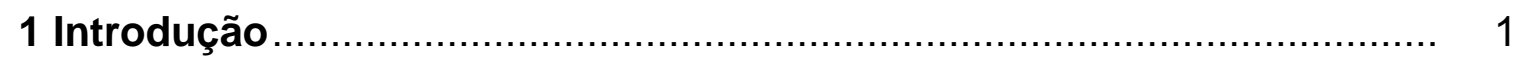

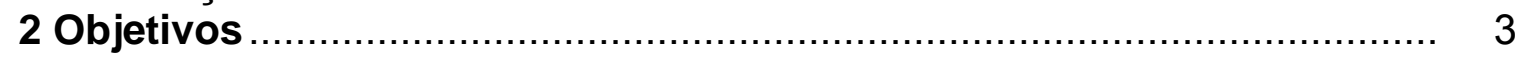

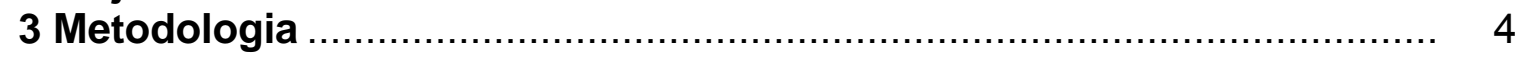

4 Elaboração de Cardápios e As Leis da Alimentação ………………..... 5

5 Princípios Gerais da Toxicologia dos Alimentos ................................ 7

5.1 Substâncias Tóxicas Naturalmente Presentes nos Alimentos................ 8

5.1.1 Glicosídios Cianogênicos ………................................................. 9

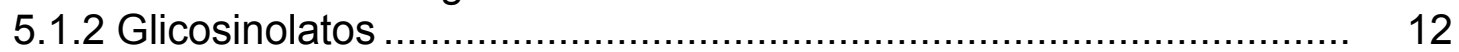

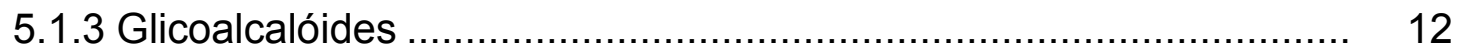

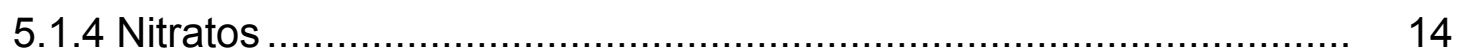

5.2 Substâncias Tóxicas Advindas do Processamento ............................... 16

5.2.1 Produtos da Oxidação Lipídica................................................. 16

5.2.2 Hidrocarbonetos Aromáticos Policíclicos (HAP) ............................ 18

5.2.3 Aminas Aromáticas Heterocíclicas(AAH) ................................... 20

5.2.4 Reação de Maillard............................................................... 21

6 Fatores Antinutricionais ....................................................... 23

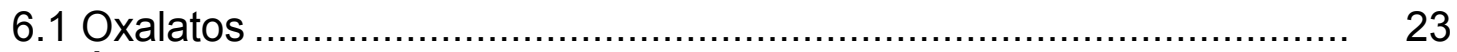

6.2 Ácido Fítico - Fitato .......................................................... 24

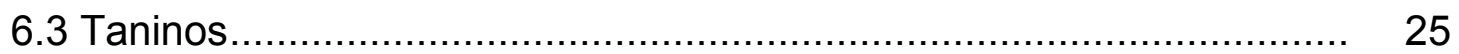

7 Conseqüências dos Agentes Tóxicos para a Saúde ………………..... 27

8 Resultado e Discussão ............................................................ 28

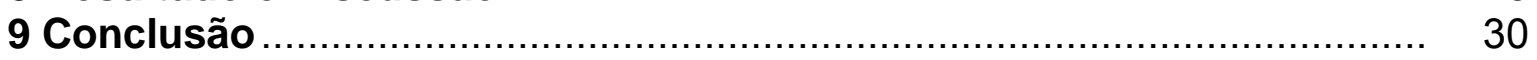

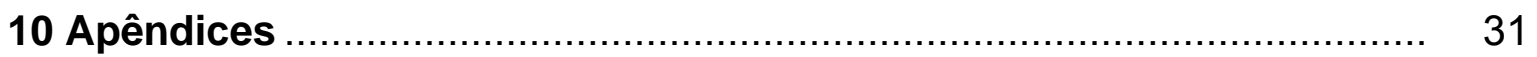

Apêndice I - Cardápio analisado da semana 01/07 à 05/07/02 …............... 32

Apêndice II - Cardápio analisado da semana 08/04 à 12/07/02 .................. 33

Apêndice III - Cardápio analisado da semana 15/07 à 19/07/02 .................. 34

Apêndice IV - Cardápio analisado da semana 22/07à 26/07/02 ................... 35

Apêndice $V$ - Cardápio analisado da semana 29/07 à 02/08/02 ................. 36

Apêndice VI - Cardápio analisado da semana 05/08 à 09/08/02 ................. 37

Apêndice VII - Cardápio analisado da semana 12/08 à 16/08/02 ................ 38

Apêndice VIII -Cardápio analisado da semana 19/08 à 23/08/02 ................ 39

Apêndice IX - Cardápio modificado da semana 01/07 à 05/07/02 ................ 40

Apêndice X - Cardápio modificado da semana 08/04 à 12/07/02 ................ 41

Apêndice XI - Cardápio modificado da semana 15/07 à 19/07/02 …............ 42

Apêndice XII - Cardápio modificado da semana 22/07 à 26/07/02 .............. 43

Apêndice XIII - Cardápio modificado da semana 29/07 à 02/08/02 .............. 44 
Apêndice XIV - Cardápio modificado da semana 05/08 à 09/08/02 .

Apêndice XV - Cardápio modificado da semana 12/08 à 16/08/02 .

Apêndice XVI - Cardápio modificado da semana 19/08 à 23/08/02 


\section{Introdução}

Alimentar-se envolve muito mais do que necessidades orgânicas. Incluem as necessidades sociais - relativa à interação do indivíduo no grupo - e as psicológicas - relacionadas à personalidade do indivíduo, aos seus conceitos, sentimentos e experiências pessoais. Desta forma, há vários fatores que influenciam o ato de alimentar-se, como a família, comunidade, padrões culturais, tradição, crenças e tabus.

O alimento é percebido pelo corpo humano através dos órgãos do sentido (olfato, tato paladar, visão e audição). As características sensoriais ou organolépticas dos mesmos são captadas por um conjunto de estímulos nervosos e levadas ao sistema nervoso central, que codifica tal mensagem e emite uma resposta para as mesmas. "O prazer de comer é a sensação atual e direta de uma necessidade que encontra satisfação" (Savarin, 1995).

O homem civilizado, o que possui o espírito crítico e livre arbítrio, produziu um efeito de perfectibilidade, dando aos órgãos maior importância, em que um passou a interferir no outro para benefício e bem-estar do "eu-sensitivo" ou indivíduo (Savarin, 1995).

O prazer da mesa é a sensação refletida que nasce de fatos, local, coisas e pessoas que estão presentes à refeição. Depois de uma refeição realizada, o corpo e o "eu" gozam de um bem-estar especial. O cérebro se "refresca", a fisionomia se alegra, as cores se acentuam, os olhos brilham e um calor se espalha pelos membros (Savarin, 1995).

A mesa reúne, também, o amor, a amizade, os negócios, as especulações, o poder, as solicitações, a proteção, a ambição e a entrega. $O$ ato de comer é muito mais abrangente na vida e na personalidade do indivíduo a todo momento; por isso, a refeição deve ser prazerosa.

Como conseqüência, observa-se, através da história, que o homem procurou modificar a maneira e o local de oferecer a refeição, proporcionando conforto, segurança, ornamentação, recipiente, talheres e local apropriados. 
No entanto, diante de um cotidiano extremamente agitado, a população não tem tempo para o almoço em casa com a família, optando por um self-service mais perto do trabalho, nem sempre priorizando o prazer de se alimentar.

A oferta desordenada de preparações nesse tipo de serviço acaba por deixar o cliente vulnerável a não variar a dieta. A monotonia da dieta contribui para a não satisfação dos requerimentos dos nutrientes, além de aumentar a possibilidade de riscos de toxicidade, determinando riscos à saúde. Estudos alertam que $35 \%$ da incidência de câncer humano tem origem na dieta.

Assim, as empresas do ramo que prestam esse serviço à coletividade devem ter, como uma de suas prioridades, a elaboração de cardápio. Para tal, deve-se partir do conhecimento do valor nutritivo e da digestibilidade dos alimentos; da filosofia da empresa quanto a benefícios; quanto às compras; mercado fornecedor/custos/rendimento do produto; da disponibilidade e capacidade de mãode-obra; disponibilidade e capacidade das instalações, equipamentos e área física; e, principalmente, do cliente.

Neste contexto o exercício profissional do nutricionista deve ser eficiente e abrangente, seja com relação à criação de novas preparações, ou ao desenvolvimento de cardápios menos repetitivos, com maior variação de alimentos e técnicas de preparo.

Portanto, a necessidade de conhecimento das substâncias químicas presentes nos alimentos, efeitos sobre o organismo e limites de ingestão diária recomendada são fundamentais para instrumentalização dos alimentos como agentes de manutenção e promoção da saúde e bem-estar da população.

De fato, o estudo da nutrição torna-se incompleto sem a consideração das substâncias tóxicas encontradas nos alimentos e a aplicação destes conceitos na elaboração de cardápios e gerenciamento de unidades de alimentação e nutrição (UAN). 


\section{Objetivo Geral}

Analisar os cardápios de oito semanas do Restaurante tipo Self-service, levando em consideração fundamentos da técnica dietética e os compostos tóxicos e antinutricionais presentes nos alimentos.

\subsection{Objetivos Específicos}

- Definir os alimentos potencialmente tóxicos ou que podem produzir compostos tóxicos nos cardápios analisados;

- Identificar, nos cardápios, a freqüência destes alimentos no período de oito semanas e os possíveis riscos à saúde;

- Modificar, nos cardápios, alimentos detectados como potencialmente tóxicos por alimentos que ofereçam menores riscos à saúde;

- Identificar os alimentos que apresentam compostos antinutricionais e verificar a freqüência no cardápio;

- Avaliar as técnicas dietéticas utilizadas e propor alterações da forma de preparo dos alimentos que possam diminuir ou eliminar compostos tóxicos e antinutricionais dos alimentos;

- Montar estratégias para orientar a clientela sobre as melhores escolhas dos alimentos nas refeições realizadas em um self-service. 


\section{Metodologia}

Inicialmente, uma pesquisa bibliográfica foi realizada constituída principalmente de livros e artigos científicos sobre os produtos tóxicos naturalmente presentes nos alimentos e os conceitos mais importantes da técnica dietética.

O trabalho foi desenvolvido em um restaurante tipo self-service da CORAL, que funciona no Ministério do Planejamento, no $9^{\circ}$ andar, no horário de 11:30 às 14:30hs, de segunda à sexta-feira.

Atende-se, por dia, uma média de 500 clientes, entre funcionários do próprio prédio e de outros Ministérios, assim como visitantes.

O cardápio executado nesta instituição é do tipo médio, composto por 7 entradas (saladas), 3 pratos principais (pratos protéicos), 2 garnições, 3 acompanhamentos, além de 1 suco e 1 refresco e 4 tipos de sobremesa (sendo 2 frutas e 2 tipos de doces), que estão incluídos no preço do quilo na proporção de 1 suco e 1 sobremesa, por pessoa.

Durante o estudo, período entre o dia $1^{\circ}$ de julho até 23 de agosto de 2002, os cardápios foram analisados, definindo-se os alimentos potencialmente tóxicos ou que poderiam produzir compostos tóxicos nos processos de cocção. Também foram analisados aspectos relacionados com a elaboração de cardápios, como cor, forma, sabor, textura, temperos, ingredientes e tipo de preparo, a fim de oferecer maior variedade e prazer na alimentação da clientela.

Após a identificação dos possíveis problemas, alterações foram propostas sem, no entanto, descaracterizar o cardápio da unidade.

É importante salientar que alguns itens no cardápio não sofreram alteração, pois se tratavam de hábito alimentar da população, tais como: alface, tomate, salada elaborada com maionese diariamente e a feijoada de 15 em 15 dias, ou mesmo toda semana, sempre às sextas-feiras. 


\section{Elaboração de cardápios e As Leis da Alimentação}

Segundo Bernardes (1997), "cardápio é definido como lista de preparações culinárias que compõe uma refeição ou lista de preparações que compõe todas as refeições de um dia ou período determinado, utilizando-se de padrões nutricionais e das técnicas dietéticas dos alimentos a fim de atender às leis da alimentação".

"De acordo com Escudero (1934), as leis que regem a alimentação são:

- Quantidade: a dieta ou regime alimentar deve atender às necessidades calóricas de cada nutriente específico, de acordo com a fase da vida do indivíduo.

- Qualidade: o regime ou cardápio só é completo quando sua composição atender a todos os nutrientes, com a presença de todos os grupos de alimentos.

- Harmonia: as quantidades dos nutrientes devem manter uma relação de proporção entre si, permitindo seu aproveitamento completo.

- Adequação: a alimentação deve ser adequada a cada fase da vida ou situação fisiológica do indivíduo."

A elaboração de cardápios é uma atividade de extrema importância, sendo a responsável pelo "ponto de partida" no planejamento das compras e na produção, pela satisfação dos clientes e pela determinação na composição dos custos, além de ser imprescindível no acompanhamento nutricional.

"O planejamento e a composição de um cardápio envolvem não apenas aspectos de ordem culinária, mas também de combinação de alimentos, dos mercados abastecedores, do gênero da clientela, das disponibilidades financeiras e, também, da capacidade de produção" (Silva \& Bernades, 2001).

Uma modalidade muito comum de apresentar refeições à clientela é o chamado Self-service por quilo ou auto atendimento, ou auto-serviço, o qual será abordado neste trabalho, onde o cliente serve-se e pesa o prato, pagando pela quantidade consumida.

Esse serviço vem sendo adotado com sucesso por restaurantes comerciais e institucionais, porém, se a oferta e a combinação dos pratos não for adequada, o 
cliente poderá consumir uma refeição totalmente desbalanceada do ponto de vista nutricional e toxicologicamente inadequada.

A alimentação equilibrada não consiste apenas na enumeração de uma série de quantidades de nutrientes e, sim, que seja agradável e apropriada ao indivíduo que a consome. As preparações e os tipos de alimentos devem ser apresentados de tal forma que o indivíduo se sinta estimulado a ingeri-la e não apresente conseqüências futuras indesejáveis. 


\section{Princípios Gerais da Toxicologia de Alimentos}

A toxicologia de alimentos pode ser definida como "ciência que estuda a natureza, fontes e formação de substâncias tóxicas em alimentos, incluindo a verificação de efeitos nocivos e o estabelecimento de limites de segurança para ingestão de determinados componentes"(Torres, 2001).

Vários alimentos, regularmente consumidos, contêm substâncias químicas diversas que são consideradas tóxicas. Algumas podem ser letais, outras interferem na digestibilidade, absorção ou utilização de nutrientes, afetando a qualidade do alimento.

Estas substâncias, em sua grande maioria, são constituintes naturais produzidos por vegetais para proteção contra ataques de pássaros, insetos e microrganismos. Em outro enfoque, substâncias tóxicas são formadas em alimentos, como resultado de métodos tradicionais de cozimento e/ou preservação (conservação e armazenamento), sendo seus efeitos biológicos diversos e complexos.

É comum que os alimentos possam estar contaminados com vários agentes tóxicos concomitantemente. Dentro do grande espectro de efeitos tóxicos é necessário que se considerem os efeitos de interação (Midio \& Martins,2000). São eles:

Efeitos tóxicos aditivos, que correspondem a simples somatória dos efeitos de substâncias que tenham o mesmo mecanismo de ação.

Efeitos tóxicos de interação por potencialização, como a capacidade que uma substância tem de potencializar a toxicidade de outra sem, contudo, isoladamente apresentar aquele efeito observado.

Efeito tóxico por sinergismo - fenômeno no qual dois agentes tóxicos produzem um efeito mais intenso, quando associados, do que em quantidades equivalentes de cada um, dadas individualmente.

E, por fim, um dos efeitos mais importantes dentro dos domínios da toxicologia de alimentos é o efeito carcinogênico/ mutagênico. 
Há ainda, aquelas substâncias adicionadas aos alimentos, conhecidas por "aditivos alimentares", entre eles, corantes, conservantes, antioxidantes, edulcorantes, que são todas substâncias ou misturas de substâncias dotadas ou não de valor nutritivo, adicionadas ao alimento com a finalidade de impedir alterações, manter, conferir ou intensificar seu aroma, cor e sabor, modificar ou manter seu estado físico geral ou exercer ação qualquer exigida para uma boa tecnologia de fabricação.

Para os agentes tóxicos veiculados pelos alimentos, quanto maior sua concentração no organismo mais intenso será o efeito produzido. A absorção de agentes tóxicos (AT) presentes nos alimentos poderá se dar em toda extensão do trato gastrintestinal (TGI), ou seja, desde a mucosa bucal até a mucosa retal. Porém, é através da mucosa das porções mais superiores do intestino delgado (duodeno) que grande parte dos AT são absorvidos eficientemente. Para a toxicologia de alimentos, entende-se por absorção o transporte do AT, através de membranas, do meio externo (TGI) para o meio interno (corrente circulatória).

Para essas substâncias tóxicas naturalmente presentes no alimento não se estabelece tolerância, uma vez que a sua concentração dependerá das condições em que o alimento foi produzido (cultivado). Entende-se por Tolerância ou Limite Máximo Permitido (LMP) "a concentração de um não-nutriente presente no alimento (expresso em termos de massa/massa ou massa/volume) que pode ser ingerido por um indivíduo, durante toda sua vida, sem que a mesma possa causar efeitos nocivos, ou seja, esteja dentro das condições de segurança" (MIDIO, 2000).

\subsection{Substâncias Tóxicas Naturalmente Presentes nos Alimentos}

A grande maioria das substâncias que compõem os alimentos consumidos pelo homem, com exceção dos nutrientes, não está, ainda, muito bem caracterizada quimicamente, e como conseqüência, muitos de seus eventuais efeitos nocivos são ainda desconhecidos.

A população humana tem estado exposta a substâncias tóxicas naturalmente presentes em alimentos, tanto de origem animal como principalmente de origem 
vegetal, por muitas gerações, conseguindo, com uma grande capacidade, conviver biologicamente com esses compostos, não obstante com uma certa desconfiança sobre sua segurança.

É necessário salientar que alimentos que contêm naturalmente agentes tóxicos em sua composição são, via de regra, consumidos em países subdesenvolvidos. Por outro lado, a busca de novos vegetais como fonte de alimentos pelos melhoristas é indistintamente relevante para todos os países. Entre essas substâncias tem-se:

\subsubsection{Glicosídeos Cianogênicos}

São compostos orgânicos constituídos por um açúcar e uma porção "nãoaçúcar", que se denomina aglicona.

A aglicona pode ser um grupo alquila, arilalquila ou arila e, geralmente, define as características dos glicosídios. Assim, quando esse grupo é representado por hidroxinitrilas (cianidrinas) pode-se classificar esse composto como um glicosídeo cianogênico.

Uma característica química muito importante dos glicosídeos é a facilidade com que se hidrolisam. Através desse tipo de reação, libera-se o açúcar e a cianidrina que, por sua vez, degrada-se originando o ácido cianídrico, que é o responsável pela toxicidade do composto.

As plantas que contêm mais que $20 \mathrm{mg}$ de cianeto por $100 \mathrm{~g}$ de peso são classificadas de alto risco de provocar intoxicações, mesmo quando ingeridas em pequenas quantidades. De modo geral, as mais altas concentrações são encontradas nas folhas, mas o composto também se apresenta em quantidades consideráveis nas raízes, sementes e outros tecidos. Os glicosídeos cianogênicos podem estar disseminados por toda planta.

Destacam-se, ainda, que tecidos jovens (brotos) apresentam concentrações mais elevadas destes compostos. Além disso, a concentração também varia entre as diversas espécies vegetais. 
A amigdalina foi o primeiro glicosídeo cianogênico isolado e caracterizado, sendo comumente encontrado nos frutos das espécies da família Rosaceae (pêra, maçã, pêssego, cereja e damasco). Nestes, as sementes podem ser altamente cianogênicas, enquanto que a polpa, utilizada na alimentação, não o é.

Já para as espécies de Sorghum, que apresentam o glicosídeo durrina, as sementes secas, usadas como alimento para humanos na Índia e África e para o gado na América do Norte, são não-carcinogênicas, porém as sementes jovens podem conter altas concentrações de durrina.

Linamarina e Lotaustralina estão presentes nas mesmas plantas, pois são sintetizadas pelas mesmas vias enzimáticas, a partir dos aminoácidos valina e isoleucina, respectivamente. Ambos são largamente distribuídos em vegetais como a mandioca e o feijão.

A hidrólise dos glicosídeos cianogênicos é amplamente favorecida quando ocorre em meio ácido. Assim, quando se ingere vegetais que contenham tais glicosídeos, estes, ao entrarem em contato com o pH do estômago, encontram um meio ideal para liberação do ácido cianídrico.

O cianeto provoca hiperpnéia por estimulação direta da carótida e dos copos aórticos. Um estado transitório de estimulação do SNC pode provocar cefaléia. A respiração, de início, é estimulada devido à resposta das células quimiorreceptoras à diminuição de oxigênio. Há convulsões hipóxicas e morte devido ao bloqueio respiratório de origem central.

O tratamento da intoxicação precisa ser rápido para ser eficaz. Consiste na injeção intravenosa do nitrito de sódio, que converte a hemoglobina a metemoglobina. Como a afinidade da metamioglobina pelo cianeto é maior, ocorre formação da cianometemoglobina e restauração da citocromo oxidase. Numa segunda etapa, administra-se tiossulfato de sódio intravenosamente, acelerando-se, assim, a conversão do cianeto, pela enzima rodanase, em tiocianeto, que é muito menos tóxico e excretado pela urina.

Estima-se que 0,5 mg a 3,5 mg de HCN por $\mathrm{Kg}$ de peso corpóreo pode levar o indivíduo à morte em poucos minutos.

Em média, $100 \mathrm{~g}$ de amêndoas amargas contêm $25 \mathrm{mg}$ de ácido cianídrico. Então, $250 \mathrm{~g}$ desse vegetal já seriam suficientes para causar uma intoxicação aguda. 
No caso de ingestão de mandioca brava, $245 \mathrm{~g}$ já seriam altamente tóxicas. No entanto, esta quantidade está relacionada com o alimento cru, situação essa que na prática normalmente não acontece.

Não é incomum ouvir-se relatos de intoxicações letais por cianeto veiculado pela mandioca. Infelizmente, não se dispõe de dados a respeito de tal incidência.

Os processos de preparação (cozimento, fritura) tendem a reduzir o teor desse agente no alimento. Some-se a isso, o fato de seus consumidores, principalmente na zona rural, reconhecerem as diversas variedades de mandioca, conseguindo separar aquelas consideradas "bravas".

Entre os fatores que influenciam a concentração de glicosídeos cianogênicos nas plantas, podem ser citados: idade, fatores sazonais, ambientais (temperatura e umidade), nutricionais (fertilizantes) e genéticos.

Casos de intoxicações crônicas ocorrem quando se ingere pequena quantidade de HCN por períodos mais longos e, principalmente, em populações na quais a mandioca é o alimento básico.

Uma das conseqüências das intoxicações crônicas por glicosídeos cianogênicos envolve o sistema nervoso. É chamada neuropatia atáxica tropical (TAN), observada em certas áreas da Nigéria e da Tanzânia. Essa síndrome é representada por uma mielopatia, atrofia óptica bilateral, surdez bilateral e polineuropatia. Pode ocorrer doença de Parkinson, degeneração cerebral, psicose e demência.

O consumo generalizado de mandioca pode ser um fator para o aparecimento de bócio. Como se sabe, o $\mathrm{HCN}$ liberado pelos glicosídeos cianogênicos é destoxificado a tiocianato. O tiocianato causa modificações no metabolismo da tireóide dificultando a retenção de iodo. Portanto, o aparecimento de bócio depende de vários fatores, principalmente da deficiência da ingestão de iodo, podendo ser agravado pelo conteúdo de glicosídeos cianogênicos no alimento, assim como a freqüência e a quantidade de mandioca que se consome (Midio \& Martins 2000). 


\subsubsection{Glicosinolatos}

Também chamados de glicosídeos tiocianogênicos ou tioglicosídeos, são compostos encontrados em inúmeras plantas de cultivo, responsáveis pelo sabor característico (picante) de condimentos como, por exemplo a mostarda e de vegetais de uso amplamente difundido, como o repolho, couve-flor, brócolis, nabo.

Os glicosinolatos são sintetizados a partir de aminoácidos.

Os tioglicosídeos podem estar presentes em todas as estruturas das plantas que os contenham, como raízes, caules, folhas e sementes. Seu conteúdo, nestes vegetais, depende da parte ou órgão em que se encontra na planta, fatores genéticos, práticas de cultivo, aplicação de fertilizantes (sulfatos e nitratos aumentam e diminuem o conteúdo dos glicosinolatos, respectivamente), natureza do solo, cozimento (perda dos glicosinolatos pela água) e outras condições de processamento, como corte, branqueamento, congelamento, fermentação, armazenamento.

A hidrólise dos glicosinolatos pode ocorrer no próprio vegetal, toda vez que este for submetido a processo de maceração, trituração (preparação de alimentos), cozimento, assim como nos intestinos de animais que se alimentam desses vegetais, liberando glicose e uma aglicona instável.

Glicosinolatos aromáticos e heterocíclicos produzem isotiocianato instável em $\mathrm{pH}$ neutro ou alcalino, que se decompõe para produzir tiocianatos orgânicos. $\mathrm{O}$ aroma e o sabor de algumas plantas crucíferas são determinados pelos produtos de hidrólise (nitrilas e isotiocianatos) e não pelos glicosinolatos propriamente.

Efeitos nocivos são observados na população exposta a estas plantas, como o bócio endêmico (Midio \& Martins, 2000).

\subsubsection{Glicoalcalóides}

São metabólitos encontrados nas diversas variedades de batatas, dos quais destacam-se, por sua importância toxicológica, os esteróides a-solanina e $\alpha$ - 
chaconina. Estes compostos, derivados biossintéticos do colesterol, são constituídos pela aglicona soladinina ligada a três resíduos de açúcares.

A a-solanina e a a-chaconina compreendem 95\% de todos os glicoalcalóides presentes nas batatas destinadas à alimentação humana.

De acordo com estudos realizados no Reino Unido, calcula-se que a batata apresenta, geralmente, concentrações de glicoalcalóides totais entre 2,5 mg a $15 \mathrm{mg} / 100 \mathrm{~g}$ dos tubérculos frescos, presentes nas partes imediatamente abaixo da casca e em locais de alta atividade metabólica, como os brotos. As altas concentrações são encontradas em batatas verdes e danificadas.

Os teores de glicoalcalóides dependem da constituição genética da planta, tipo de solo para o cultivo, fatores climáticos e geográficos, além das condições de armazenamento, que podem influir aumentando a síntese dos mesmos como, por exemplo, excesso de exposição à luz, retardamento da maturação, danos mecânicos.

O cozimento parece não reduzir a concentração dos glicoalcalóides totais. Batatas cozidas ou assadas, contendo teores acima de $11 \mathrm{mg} / 100 \mathrm{~g}$, apresentam gosto amargo.

A ingestão de batatas contendo altas concentrações de glicoalcalóides tem sido associada a intoxicações produzidas tanto no homem como em outros animais. Batatas contendo $38 \mathrm{mg}$ a $45 \mathrm{mg}$ de solanina por $100 \mathrm{~g}$ de tubérculo são apontadas como a causa provável de intoxicações fatais em humanos.

O quadro clínico envolve sintomas gastrointestinais e neurológicos, possivelmente devido à atividade anticolinesterásica da solanina. Podem ser observadas alterações hemolíticas e hemorrágicas no trato gastrintestinal e na retina. Os glicoalcalóides (a-chaconina) também são associados a efeitos teratogênicos para camundongos e hamsters. A incidência de malformações em humanos está relacionada, principalmente, para os casos de anencefalia e espinha bífida.

Apesar de todos os fatores envolvidos na presença dos glicoalcalóides na batata, e em virtude dos seus possíveis efeitos tóxicos em humanos, concorda-se que sua concentração não deva exceder a $20 \mathrm{mg} / 100 \mathrm{~g}$ do tubérculo fresco a fim de não causar danos à saúde da população exposta. Este é um dos poucos casos, para 
agentes tóxicos naturalmente presentes nos alimentos em que se estabelece um limite de tolerância.

Glicoalcalóides podem ser encontrados também em outras solanáceas, tais como a berinjela (Solanum melongena) e o tomate (Lycopersicon esculentum).

\subsubsection{Nitratos}

O íon nitrato $\left(\mathrm{NO}_{3}\right)$, base conjugada do ácido nítrico, forma sais hidrossolúveis com $\mathrm{Na}^{+}, \mathrm{K}^{+}$e $\mathrm{Ca}^{++}$, amplamente disseminados no ambiente. Sua formação no ambiente ocorre através de um processo de oxidação biológica, a partir do íon amônio.

Estas reações são mediadas por microrganismos do solo, como as nitrosomonas, que oxidam o íon amônio a nitrito, realizando a primeira etapa da reação, e as nitrobactérias, que oxidam o nitrito a nitrato, tornando este último mais abundante no ambiente.

Nitratos estão, assim, presentes no solo, na água e nos vegetais e, portanto, distribuídos em alimentos de origem vegetal e animal.

São, também, utilizados como aditivos intencionais de alimentos, nas formas de seus sais de sódio e potássio, em conservas, produtos cárneos e queijos. Outras funções desses sais na industrialização de alimentos são: conferir cor e sabor a carnes e peixes curados e prevenir o estufamento tardio de queijos.

Os nitratos não podem ser considerados compostos de alto risco em provocar intoxicações, apesar de existir evidências de que podem interferir no metabolismo da vitamina A e nas funções das glândulas tireóides. Nas quantidades normalmente encontradas nos alimentos (quer seja naturalmente ou como aditivo intencional) e sob as condições nas quais são ou podem ser reduzidos a nitritos, os principais riscos toxicológicos associados à ingestão do íon nitrato são: a produção de metemoglobina (principalmente na população infantil), quando há formação de nitrito, e a formação de compostos $\mathrm{N}$-nitrosos (compostos carcinogênicos), principalmente as nitrosaminas, tanto no alimento como no organismo. 
A água é a principal fonte de nitratos para a população humana. Seus teores, nas águas de abastecimento urbano, de poços domésticos ou artesianos podem oscilar de praticamente zero até $200 \mathrm{mg} / \mathrm{L}$. No Brasil, esse limite é de $10 \mathrm{mg} / \mathrm{L}$.

Os níveis de nitratos, por vezes elevados, em vegetais utilizados na alimentação humana, são devido:

- Solos ricos em nitratos e compostos nitrogenados, provocados pelo uso excessivo de fertilizantes;

- Liberação do nitrato proveniente da matéria orgânica do solo, através de atividade microbiana, temperatura e umidade;

- Variedades genéticas propensas ao acúmulo de nitratos;

- Deficiência de alguns nutrientes como P, K e Ca;

- Pouca luminosidade e baixa irrigação;

- Processo de maturação do vegetal e armazenamento pós-colheita.

A temperatura e o tempo de armazenamento dos vegetais são fatores importantes para a diminuição dos níveis de nitratos com o aumento proporcional dos de nitritos, responsáveis pelos efeitos tóxicos na população que ingere esses alimentos.

Acredita-se que no leite fluido, os teores de nitratos dificilmente ultrapassariam $5 \mathrm{mg} / \mathrm{L}$, sendo que, para o leite em pó, as concentrações não seriam tão diferentes. Duarte e Mídio (1996) ainda afirmam que a concentração de nitratos em soro é maior se comparada com a do leite, podendo ocorrer, também, a presença de nitritos.

Para nitratos naturalmente presentes em alimentos de origem vegetal, não são estabelecidos tolerância ou limites máximos permitidos. Porém, a legislação brasileira considera impróprio para o consumo o leite de gado que contenha nitratos.

A Ingestão Diária Aceitável (IDA) para nitratos, segundo a Organização Mundial da Saúde, não deve ultrapassar $3,7 \mathrm{mg} / \mathrm{Kg}$ peso corpóreo, não podendo ser aplicada a crianças menores de 3 meses de idade. 


\subsection{Substâncias Tóxicas Advindas do Processamento}

Os alimentos possuem substâncias nutritivas e outros compostos, sendo que todos os componentes constituem substâncias reativas e, portanto, reagem entre si. Esses ingredientes alimentares podem reagir com contaminantes durante 0 processamento e, principalmente, durante o período de armazenamento.

Pode-se intensificar ou retardar a ocorrência de reações através da aplicação de variações de temperatura, tanto no processamento quanto no preparo de alimentos.

\subsubsection{Produtos da Oxidação Lipídica}

A fração lipídica dos alimentos está relacionada a diversas propriedades organolépticas, como aroma, coloração, textura, suculência, estabilidade das proteínas, vida de prateleira sob congelamento e conteúdo calórico.

A oxidação e hidrólise de ácidos graxos insaturados produz um dialdeído carcinogênico, o malonaldeído. Os óxidos de colesterol são formados através da oxidação do colesterol, sendo considerados carcinogênicos e, portanto, potencialmente mais prejudiciais ao organismo do que a ingestão de colesterol e seu efeito negativo de aumento do risco de ocorrência de doenças cardíacas.

A oxidação do colesterol pode ser acelerada pelo aquecimento, $\mathrm{pH}$, condições de armazenamento (luz e oxigênio) e presença de catalisadores.

Larkeson et al. (2000) demonstraram que produtos da oxidação de colesterol na dieta levam a efeitos adversos. Verificaram, também, que em carnes congeladas, após fritura, os teores de óxidos aumentam consideravelmente.

São diversas as conseqüências nutricionais da oxidação lipídica: destruição parcial dos ácidos graxos insaturados essências linoléico e linolênico; destruição parcial de outros lipídios insturados, como a vitamina A, carotenóides e tocoferóis e destruição da vitamina $C$. 
Um estudo realizado no Brasil (SICHIERI et al, 1996) revelou associações positivas entre o consumo de gordura e a ocorrência de cânceres esofagianos e intestinais (cólon).

O problema da oxidação lipídica é muito relevante no tocante à questão da alimentação e nutrição do homem. Além da deterioração da qualidade sensorial e nutricional dos alimentos, as substâncias tóxicas produzidas contribuem para a ocorrência de processos como aterosclerose e câncer.

No caso de toxicidade, os compostos formados vão depender da composição da gordura e do alimento que foi frito.

Estudos demonstraram que ingestão crônica de lipídios oxidados pode ser de risco, já que foram relacionados com o aumento da freqüência de tumor e incidência de aterosclerose.

Atualmente, sabe-se que o aquecimento de carnes e outros alimentos promovem a formação de produtos da reação de Maillard que reagem com produtos da oxidação lipídica originando as aminas aromáticas heterocíclicas(AAH).

Outro problema é a liberação ambiental de vapores irritantes (da pele e mucosa) e cancerígenos, que podem colocar em risco cozinheiros e outros funcionários de cozinha, além de profissionais de nutrição.

Este é o ponto onde a gordura começa a liberar fumaça, iniciando a clivagem de lipídios, com a liberação de ácidos graxos livres e acroleína (derivada do glicerol).Quanto maior a temperatura do ponto de fumaça, mais lenta a degradação.

A acroleína está presente em fumaças de tabaco, combustão de fósseis e gordura vegetal. Ė extremamente tóxica para o homem, com dose oral letal entre $5 \mathrm{e}$ $50 \mathrm{mg} / \mathrm{Kg}$, mas os informes sobre toxicidade crônica são escassos(IPCS, 1992)

Defeitos no feto foram observados em outros animais, mas somente quando acroleína era injetada diretamente no tecido embrionário.

$\mathrm{Na}$ forma aguda, a acroleína age primeiramente como irritante dos olhos e trato respiratório. A NOEL (Nível de dose sem efeito em $\mathrm{mg} / \mathrm{Kg} / \mathrm{peso} / \mathrm{dia}$ ) para irritação dos olhos é de 0,06 ppm de acroleína por 5 minutos. 


\subsubsection{Hidrocarbonetos Aromáticos Policíclicos (HAP)}

Os HAP ocorrem como contaminantes em diferentes grupos de alimentos, incluindo vegetais, frutas, carnes, óleos e gorduras, grãos, bebidas, alimentos grelhados, torrados e de origem marinha. São provenientes, principalmente, de processamentos como defumação, secagem, torrefação, alguns tipos de cozimento, embalagens, assim como da poluição.

Os HAP são formados em carnes pela pirólise da gordura à temperatura elevada. Estes, presentes na fumaça oriunda da gordura pirolisada são, então, absorvidos pela carne. A concentração de HAP depende do teor de gordura da carne, do processo de aquecimento, podendo se encontrados em quantidades de até $50 \mathrm{ppm}$.

Após a ingestão, os hidrocarbonetos aromáticos policíclicos são metabolizados para derivados intermediários benzo[a]pireno(BAP), benzo[a]antraceno, criseno, pireno, benzo(k)fluorenteno, responsáveis por seu efeito carcinogênico.

O BAP é um dos mais estudados e é um indicador para potencial toxicológico. Sua presença foi identificada impregnada a alimentos (carnes e peixes) submetidos a cozimento direto em fogo de lenha, carvão ou outros combustíveis.

Contudo, são nos alimentos defumados que os HAP, principalmente o BAP, podem ser encontrados com maior freqüência. A queima de celulose, hemicelulose e lignina produz a fumaça que, além de conter as substâncias responsáveis pelo sabor, aroma, ação conservante e antioxidante e coloração do produto, carrega também essas substâncias indesejáveis.

Numerosos estudos epidemiológicos têm mostrado associação entre exposição a várias misturas de HAP contendo benzo[a]pireno e o aumento do risco de produção de câncer em pulmão e outros tumores. Chiang et al (1999) observaram que a fumaça dos óleos continha HAP e poderia haver aumento de desenvolvimento de câncer de bexiga.

Pesquisadores observaram que carnes com gordura apresentam até 7 vezes mais BAP que as sem gordura. Também avaliaram a utilização de carvão prépirolisado e a madeira, como fonte de calor para cocção, onde, utilizando-se 
madeira, as concentrações de BAP foram superiores ao uso de carvão. Os mesmos relataram também níveis médios de benzo(a)pireno de 16,41 a $0,10 \mu \mathrm{g} / \mathrm{Kg}$, respectivamente, em churrasco de picanha assada com e sem gordura.

A principal fonte de formação de HAP, no caso do churrasco assado sobre carvão, é a gordura que vai gotejando sobre a brasa, levando à pirólise e à formação dos HAP, que retornam à superfície da carne com a fumaça. Outro importante fator é a distância desta fonte de calor, evidenciando que, quanto maior a distância menor a contaminação.

Elevados teores de $\mathrm{B}(\mathrm{a}) \mathrm{P}$ em óleos de milho foram confirmados por vários autores. Camargo e Toledo (1998) evidenciaram que os diferentes procedimentos utilizados na refinação de óleos são responsáveis pela variação nos teores encontrados para diferentes marcas analisadas. Óleo de milho - 1,6 a 58,9 $\mu \mathrm{g} / \mathrm{Kg}$; Creme vegetal - 4,1 a 7,1 $\mu \mathrm{g} / \mathrm{Kg}$; Margarina - 1,7 a 3,9 $\mathrm{\mu g} / \mathrm{Kg}$; Maionese - 1,0 a $21,7 \mu \mathrm{g} / \mathrm{Kg}$.

Recomenda-se que a cocção seja feita em baixas temperaturas (óleo), com melhor ventilação e adição de antioxidantes reduzindo, assim, a produção de carcinógenos na fumaça. A cocção em microondas não produz HAP.

Os vegetais também estão entre as principais fontes de benzo(a)pireno na dieta humana, especialmente quando cultivados em áreas com maior poluição ambiental. Os teores de HAP encontrados nas superfícies dos vegetais ou na casca das frutas serão maiores dos que nos tecidos internos, sendo as plantas com maior área superficial de exposição, como é o caso de alfaces, couves e espinafres, as mais susceptíveis à contaminação.

Os níveis de HAP presentes nos vegetais e nas frutas dependem, principalmente, da localização das áreas de cultivo. Larsson e Sahberg (1981) determinaram níveis de benzo(a)pireno de até $18 \mu \mathrm{g} / \mathrm{Kg}$ em amostras de alfaces retiradas de uma horta perto de uma fábrica de produção de alumínio.

O açúcar é outro alimento que pode estar contaminado por HAP, devido à colheita da cana-de-açúcar no Brasil geralmente ser feita após a queima dos canaviais, liberando esses produtos que se concentram na mesma.

Pesquisa realizada no Brasil por Camargo (2001) mostrou que três são os grupos de alimentos que mais contribuem para ingestão diária de HAP totais: óleos e 
gorduras, açúcares e carnes, com valores, respectivamente, de 1,32;0,95 e 0,90 $\mu \mathrm{g} /$ pessoa/dia. A ingestão total de HAP através da dieta média nacional foi estimada em 6,15 $\mu \mathrm{g} /$ pessoa/dia, sendo que $1,90 \mu \mathrm{g} /$ pessoa/dia corresponde à fração carcinogênica.

No Brasil, a legislação vigente recomenda que os aromatizantes/aromas de fumaça não poderão resultar em mais de 0,03 ppb de BAP no alimento final (Resolução n 104/93, da Agência Nacional de Vigilância Sanitária, de 14 de Maio de 1993). A portaria $n^{\circ} 36$ - MS de 19 de Janeiro de 1990, estabelece limite máximo de $0,01 \mu \mathrm{g} / \mathrm{L}$ de benzo(a)pireno em águas potáveis.

\subsubsection{Aminas Aromáticas Heterocíclicas (AAH)}

"São compostos encontrados em carnes e peixe que sofreram processos de frituras, assados, grelhados, churrascos, ensopados e refogados" (Bailey e Willians, 1993).

Os compostos precursores são aminoácidos, creatina ou creatinina e, em alguns casos, açúcares. A creatina, durante o processamento, é convertida à creatinina, que se complexa com os aminoácidos para formar as aminas heterocíclicas.

A temperatura e o tempo de cocção possuem papel importante na produção das $\mathrm{AAH}$. À medida que a temperatura aumenta, há formação destes compostos, da mesma maneira que o tempo de cocção prolongado contribui para uma maior quantidade de aminas no alimento processado.

"As aminas aromáticas heterocíclicas são potentes mutagênicos e carcinogênicos para várias espécies de animais de experimentação" (IARC, 1993; Skog et al,1995). Alguns estudos epidemiológicos em humanos mostraram um aumento do risco de câncer de cólon e de pâncreas com o consumo de carne bem passada(Knize et al,1997).

É interessante salientar que carnes processadas em microondas apresentam menores quantidades de $\mathrm{AAH}$, quando comparadas com o métodos de cocção que 
empregam altas temperaturas. Um peito de frango grelhado ainda branco pode apresentar mais $\mathrm{AAH}$ do que aquele marinado (mais escuro).

Em relação à dieta, o aumento da concentração de gordura aumenta a conversão de $\mathrm{AAH}$ em mutágenos bacterianos. Observou-se que o óleo de oliva apresenta maior resposta, se comparado ao óleo de girassol.

Outro fator importante está relacionado com o aumento da ingestão de fibras, onde ocorre a diminuição da mutagenicidade de $\mathrm{AAH}$.

\subsubsection{Reação de Maillard}

O tratamento térmico de alimentos ricos em açúcares redutores pode resultar na Reação de Maillard, que se constitui na reação do grupo amino dos aminoácidos, peptídios e proteínas com o grupo carbonila livre dos açúcares, causando mudanças na coloração, no sabor, aroma, nas propriedades funcionais e no valor nutricional dos alimentos (Sgarbieri, 1996).

A reação de Maillard é altamente dependente da temperatura e do $\mathrm{pH}$.

Vários são os fatores da Reação de Maillard, passando pelo arranjo de Amadori, pela degradação de Strecker, finalizando com a conversão de precursores de baixo peso molecular (furfurais, redutonas, etc.) em pigmentos de cor marrom, de alto peso molecular, denominado melanoidinas (Cheftel e Cheftel, 1988).

A separação dos efeitos nutricionais dos efeitos puramente toxicológicos se constitui numa tarefa muito difícil. Uma das razões é a complexidade da reação, com um número muito grande de compostos envolvidos.

Segundo Sgarbieri (1996), nutricionalmente, a reação de Maillard pode acarretar perda de biodisponibilidade de lisina e de outros aminoácidos, perda de digestibilidade de proteína, perda de solubilidade e de outras propriedades funcionais da proteína, alterações de cor e das propriedades sensoriais da proteína e formação de compostos de degradação (ou polimerização) que podem apresentar toxicidade. 
Os caramelos, relacionados quimicamente aos produtos da reação de Maillard, têm sido apontados como causadores de linfocitopenia e do aumento de outras frações dos leucócitos.

Enquanto alguns trabalhos mostram a mutagenicidade dos compostos relacionados com a reação de Maillard, outros evidenciam sua não mutagenicidade, como sugerem Marko et al (2002), sendo o primeiro estudo a demonstrar atividade antitumoral desses produtos.

De acordo com Brands et al (2000), a mutagenicidade varia conforme o tipo de açúcar. Verificou-se que a lactose não apresentou mutagenicidade, diferentemente da glicose e da frutose.

Entretanto, de uma maneira geral, a coloração marrom dos alimentos está associada com mutagenicidade. 


\section{Fatores Antinutricionais}

São todas aquelas substâncias que, de alguma forma, provocam destruição de nutrientes essenciais ou alteram a digestão, a absorção e o metabolismo do organismo.

Estão presentes em vários tipos de alimentos como hortaliças, leguminosas e cereais. Seus efeitos podem ser minimizados, dependendo do processamento destes alimentos. Os grupos mais comumente encontrados nos alimentos são oxalatos, fitatos e taninos.

\subsection{Oxalatos}

São encontrados em maiores concentrações em espinafre, beterraba, cenoura, alface, feijão, amendoim, cacau, chás, chocolates e farelo de trigo.

O fato de oxalatos poderem se ligar ao cálcio, formando oxalatos de cálcio insolúvel conduz à hipótese de que a ingestão de plantas contendo altas concentrações de oxalatos levaria a uma redução na absorção de cálcio, interferindo no seu metabolismo, podendo ocorrer hipocalcemia e raquitismo, no caso de uma exposição crônica.

Entretanto, essa situação só seria possível com a combinação impossível de circunstâncias, ou seja, ingestão de altas concentrações de oxalatos e baixas concentrações de cálcio e vitamina $\mathrm{D}$, por um período prolongado de tempo.

Sabe-se que o cozimento dos alimentos com água reduz, em grande parte, os oxalatos solúveis (de potássio e de sódio); porém, os insolúveis (oxalatos de cálcio) praticamente permanecem no vegetal.

Do ponto de vista toxicológico, os oxalatos poderão ser nocivos à saúde humana sempre que ingeridos em excesso, por períodos breves (intoxicação aguda) ou, ainda, em concentrações normalmente presentes nos alimentos por períodos de tempos prolongados, nas dietas pouco variadas (intoxicações crônicas). 
Essas intoxicações crônicas levam a danos renais, decorrentes do bloqueio provocado por cristais de oxalatos de cálcio, com a produção de cálculos renais.

\section{2 Ácido Fítico - Fitatos}

Ocorre naturalmente em produtos de origem vegetal e interferem na absorção de microelementos essenciais ( $\mathrm{Ca}, \mathrm{Mg}, \mathrm{Fe}$ e $\mathrm{Zn}$ ). É encontrado em concentrações elevadas em cereais (germes e farelos) e legumes.

Os fitatos representam uma classe complexa de compostos de ocorrência natural formados durante o processo de maturação de sementes e grãos de cereais.

Durante a estocagem, fermentação, germinação, processamento e digestão dos grãos e sementes, o ácido fítico pode ser parcialmente desfosforilado para produzir compostos pentafosfato (IP 5), tetrafosfato (IP 4), triofosfato (IP 3), inositol difosfato (IP 2) e monofosfato (IP1), por ação de fitases endógenas.

Somente IP5 e IP6 têm efeito negativo na biodisponibilidade de minerais. Geralmente, os cátions divalentes como cálcio, zinco, ferro e cobre formam, com o ácido fítico, sais insolúveis penta e hexa substituídos.

Brune et al (1992), estudaram a absorção de ferro, em vários tipos de pães, por seres humanos. Estes autores concluíram que o inositol tri, tetra, penta e hexafosfato inibem a absorção de ferro, sendo que a fermentação utilizada no processo de fabricação de pães melhora a biodisponibilidade de ferro.

Pesquisadores obtiveram menor relação fitato/zinco e fitato/cálcio em leguminosas e cereais cozidos, em comparação aos grãos crus, devido ao decréscimo do conteúdo de fitato, principalmente em grãos que foram assados a $250^{\circ} \mathrm{C}$.

O fitato pode ser um constituinte comum de fórmulas infantis, quando houver ingestão de fórmulas preparadas com cereais, soja e outras leguminosas, podendo formar fortes complexos com cálcio, ferro, zinco e manganês. Sugere-se que a adição de fosfopeptídeos da caseína (do leite) em fórmulas infantis preparadas com soja ou a base de cereais pode ter um efeito positivo na biodisponibilidade de zinco e cálcio. 
A habilidade do fitato em ligar-se a metais, particularmente ao ferro, pode explicar sua ação antioxidante e anticarcinogênica (Messina, 1991; Jariwalla, 1992).

Em função da propriedade antioxidante, o ácido fítico pode ser usado como conservante natural muito versátil na indústria de alimentos, preservando a hidrólise de óleo de soja e a rancidez em carnes e estabilizando agentes que conferem cor aos alimentos.

O interesse nutricional na ação do fitato foi primordialmente enfatizado por seu efeito adverso na absorção de minerais e os dados sobre prevenção de câncer e cálculos renais, embora sejam limitados, sugerem uma nova visão da ação do fitato no organismo humano.

\subsection{Taninos}

São compostos fenólicos solúveis em água com habilidade para precipitar proteína. Mais especificamente, os taninos são compostos de alto peso molecular, que contêm suficientes grupos hidroxila fenólica para permitir a formação de ligações cruzadas estáveis com proteínas.

Os taninos estão presentes na fração fibra alimentar de diferentes alimentos e podem ser considerados indigeríveis ou pobremente digeríveis. Em leguminosas e cereais os taninos têm recebido considerável atenção, por causa de seus efeitos adversos na cor, sabor e qualidade nutricional.

São considerados potentes inibidores de enzimas devido a sua complexação com proteínas enzimáticas. Apresentam habilidade para interagir e precipitar proteínas como a gelatina, e parecem ser responsáveis pela adstringência de muitas plantas.

O método mais efetivo de remoção de tanino nas leguminosas é a descorticação dos grãos, resultando em perda de $83 \%$ a $97 \%$ do tanino. Encontrouse liberação do tanino do grão para o caldo durante o processo de cozimento. 
A dieta do ser humano, de uma maneira geral, possui vários alimentos contendo considerável quantidade de taninos, tais como feijões secos, ervilhas, cereais, folhas, vegetais verdes, café, chá, cidra e alguns tipos de vinho.

Apesar da ação negativa do tanino no valor nutritivo de certos vegetais, em particular na redução da digestibilidade de proteínas, na inibição da ação de enzimas digestivas e interferência na absorção de ferro, os efeitos do tanino na saúde humana ainda são questionáveis devido à limitação de estudos nesta área. É importante considerar que o tanino também apresenta uma forte ação antioxidante que, provavelmente, poderá ser mais explorada em relação aos estudos na área de conservação de alimentos e ação no organismo humano.

Considerações epidemiológicas indicam alguma evidência da relação entre câncer esofágico e ingestão elevada de tanino. 


\section{Conseqüências dos Agentes Tóxicos para a Saúde}

Através de estudos epidemiológicos e experimentos em animais de laboratório, a etiologia mais provável para o câncer na população humana pode estar relacionada com seu estilo de vida, ou seja, uso do tabaco e seus produtos, grande consumo de bebidas alcoólicas e fatores relacionados com a dieta (presença de contaminantes denominados de carcinógenos químicos, excessiva ingestão calórica, bem como a ausência de micronutrientes antioxidantes como os carotenóides, selênio e vitaminas A, C e E).

Portanto, cerca de $70 \%$ dos tumores produzidos em humanos estão intimamente relacionados com a dieta (MIDIO \& MARTINS, 2000).

Além do efeito carcinogênico, pode-se considerar também o efeito mutagênico (onde um componente tóxico age sobre o DNA, provocando alterações); efeito teratogênico (ocorrendo má formação de tecidos e órgãos nos primeiros 3 meses de gestação; e o efeito fetotóxico (substâncias químicas agem em órgãos em desenvolvimento, podendo resultar em retardo de crescimento).

A toxicidade destas substâncias é determinada não somente por suas propriedades químicas e biológicas, mas também pelo nível de exposição e duração a que o indivíduo é submetido. As toxinas naturais não apresentam problemas agudos aos consumidores, ao contrário de outros efeitos, exposições a baixas concentrações do carcinógeno através da dieta com alta freqüência de exposição são muito mais eficientes para o aparecimento do efeito do que altas concentrações com baixa freqüência.

O Comitê sobre Dieta, Nutrição e Câncer dos Estados Unidos elaborou recomendações alimentares visando reduzir o risco para alguns cânceres. As sugestões incluem redução na ingestão de energia proveniente da gordura da dieta, bem como aumento do consumo de fruta, verduras e cereais integrais. Desta forma, a variedade de uma dieta é o meio mais claro e eficaz na prevenção de doenças relacionadas ao consumo excessivo de alimentos com uma carga toxicológica elevada. 


\section{Resultados e Discussão}

Nos cardápios analisados, as preparações que deveriam ser alteradas foram marcadas com a cor vermelha e as substituições foram feitas de cor verde, levandose em consideração as normas de técnica dietética e princípios de toxicologia dos alimentos.

Teve-se como preocupação inicial os pratos principais, constituídos principalmente de carnes, por esses alimentos estarem entre aqueles que mais contribuem para ingestão diária de HAP como cita a pesquisa realizada por Camargo (2001). Observou-se, então, a forma de preparação de cada um, realizando num mesmo dia, três tipos de processamento diferentes, podendo ser grelhado, frito, assado ou cozido.

Com o consentimento da empresa Coral, pôde-se retirar dos cardápios o churrasco de toda semana, deixando-o apenas de 15 em 15 dias. Evita-se, com isso, que o cliente faça ingestão ainda maior de carnes. Nas quartas-feiras, dia de churrasco, as outras opções ficaram com preparações à base de ovo e peixes. Vale ressaltar que o mesmo é feito em churrasqueira elétrica, a qual não provoca fumaça da pirólise da carne com a brasa; conseqüentemente, as carnes não são impregnadas pelos HAP, diminuindo o risco de toxicidade.

Os cardápios apresentavam uma grande repetição de preparações à base de batatas durante toda a semana, deixando os clientes suscetíveis a essa escolha, com risco de ingestão de a-solanina e a-chaconina. Este cuidado foi tomado, mesmo apesar de todo cuidado na hora do recebimento de batatas, não permitindo aquelas esverdeadas e danificadas e a realização eficiente do pré-preparo com retirada da casca.

Ainda foram feitas alterações visando os princípios de técnica dietética.Por exemplo, a cor: trocaram-se as sobremesas que, no mesmo dia, eram abacaxi e melão, por frutas coloridas como mamão e melancia; a textura e modo de processamento: duas frituras no mesmo dia, no prato principal, trazendo problemas com o excesso de gordura, com a oxidação de lipídios e seus efeitos negativos de aumento do risco de ocorrência de doenças cardíacas e com a formação de acroleínas na fumaça, prejudicando o bem estar do funcionário. 
Algumas preparações não foram alteradas por se tratar de hábito alimentar da população em geral, como a inclusão diária de alface e tomate, e da população do restaurante estudado em específico, como salada elaborada com maionese também diariamente, feijoada todas as sextas-feiras ou de 15 em 15 dias. Porém, teve-se a preocupação, nas saladas, com o tipo de corte e de preparo realizado de modo a conseguir melhor variedade. Foram realizados cortes do tipo à Juliana, cubos, tiras, rodelas e meia-lua; cenoura e beterraba ralada e cozida alternadamente.

Outro ponto relevante é o fato de se ter no cardápio dois tipos de doce todos os dias, de sobremesa. Estes não devem ser incentivados pelos nutricionistas; porém, neste caso, eles fazem parte do contrato firmado com o órgão.

Os refrescos (bebidas artificiais) não foram analisados, pois estes apresentam apenas os agentes tóxicos adicionados aos alimentos, os quais não foram objetos de estudo neste trabalho.

Com relação aos agentes antinutricionais, percebeu-se que estes podem ser eliminados com o processamento do alimento, como exemplo: cozimento, fermentação no processo de fabricação de pães e na descorticação dos grãos, devendo-se apenas ter o cuidado de não fazer consumo excessivo dos alimentos que os contenham, repetidamente.

Ao se fazer as substituições nos cardápios tinha-se em mente que o cliente deveria estar se alimentando de forma a atingir suas necessidades nutricionais, concomitantemente com a preocupação de não fazer ingestão de quantidades excessiva dos agentes tóxicos naturalmente presentes nos alimentos, os quais foram abordados durante toda pesquisa e, acima de tudo, o de alimentar-se com prazer, levando em consideração os hábitos alimentares da população brasileira e de modo particular dos clientes desse restaurante. Dessa forma, objetivou-se promover e manter a saúde da população. 


\section{Conclusão}

A ingestão de alimentos é uma das principais vias de exposição do homem a diferentes compostos, visto que uma mistura complexa de agentes químicos é encontrada na dieta.

A minimização dos efeitos negativos, especialmente em termos toxicológicos, associada à maximização dos efeitos positivos dos alimentos, incluindo os benefícios terapêuticos, constituirá a nova tendência em consumo alimentar no âmbito da quantidade e qualidade de alimentos disponíveis à população.

Diante desses fatos, tem-se a importância de uma alimentação diversificada, variando os tipos de alimentos consumidos, bem como sua forma de preparação.

É preciso informar ao cliente como variar sua alimentação, por meio de cartazes, relacionando as melhores escolhas, orientações individuais de como se alimentar adequadamente, palestra em dias especais e ainda colocando à mostra, no restaurante, pratos exemplos, onde o cliente poderá visualizar uma alimentação balanceada com as preparações do próprio dia. Além disso, o cliente terá a oportunidade de visualizar uma montagem de preparações que não ofereçam uma ingestão elevada de compostos tóxicos à saúde.

Com a preocupação de oferecer alimentos preparados de formas variadas e com cores contrastantes, o nutricionista estará incentivando o ato de alimentar-se com prazer e o cliente sentirá vontade de comer em um estabelecimento que possua profissionais que investem nas refeições oferecidas.

As modificações realizadas nos cardápios não trouxeram problemas na operacionalidade da unidade de alimentação. Não ocorreu aumento de custos das refeições, assim como não foi necessária contratação de novos funcionários. Mas vale ressaltar que treinamentos constantes para esses funcionários devem ocorrer, trazendo melhorias na qualidade da refeição tendo, os mesmos, papel muito importante para se conseguir todos os objetivos propostos.

Enfim, verificou-se que o cliente, diante de todas as opções oferecidas no restaurante estudado, tem opção de se alimentar adequadamente, suprindo todas as suas necessidade de nutrientes e ainda minimizando os riscos de toxicidade à saúde. 
10 APÊNDICES 
Apêndice I

CORAL - Servicos de Refeicões Industriais Ltda PERÍODO: 01/07 à 05/07/02

\begin{tabular}{|c|c|c|c|c|c|}
\hline COMPOSIÇÃO & SEG - FEIRA & TER - FEIRA & QUAR - FEIRA & QUIN - FEIRA & SEX - FEIRA \\
\hline ENTRADA & $\begin{array}{l}\text { Salada de } \\
\text { Macarrão } \\
\text { Alface/ Tomate } \\
\text { Chicória/ Vagem } \\
\text { Beterraba ralada } \\
\text { Abacaxi }\end{array}$ & $\begin{array}{l}\text { Salpicão } \\
\text { Vegetariano } \\
\text { Alface/ Tomate } \\
\text { Agrião/ Chuchu } \\
\text { Picles/ Melancia }\end{array}$ & $\begin{array}{l}\text { Salada Primavera } \\
\text { Alface/ Tomate } \\
\text { Acelga/ Cenoura } \\
\text { coz. } \\
\text { Maxixe/ Mamão }\end{array}$ & $\begin{array}{l}\text { Torta fria } \\
\text { Alface/ Tomate } \\
\text { Beterraba coz. } \\
\text { Abóbora / Rúcula } \\
\text { Uva }\end{array}$ & $\begin{array}{l}\text { Salada Coral } \\
\text { Alface/ Tomate } \\
\text { Espinafre/ } \\
\text { Abobrinha } \\
\text { Cenoura cozida } \\
\text { Laranja }\end{array}$ \\
\hline PRATOS PRINCIPAIS & $\begin{array}{l}\text { Frango crocante } \\
\text { Bife à Rossini } \\
\text { Lagarto recheado }\end{array}$ & $\begin{array}{l}\text { Rocambole de } \\
\text { frango } \\
\text { Bourguignon } \\
\text { Bisteca grelhada }\end{array}$ & $\begin{array}{l}\text { CHURRASCO } \\
\text { Carne moída com } \\
\text { azeitona } \\
\text { Peixe à Barcelona }\end{array}$ & $\begin{array}{l}\text { Frango grelhado } \\
\text { Tornedor ao } \\
\text { molho Rotty } \\
\text { Almôndega } \\
\text { recheada }\end{array}$ & $\begin{array}{l}\text { Feijoada } \\
\text { Bife acebolado } \\
\text { Enroladinho de } \\
\text { peixe }\end{array}$ \\
\hline GUARNIÇÕES & $\begin{array}{l}\text { Farofa com passas } \\
\text { Batata ao forno }\end{array}$ & $\begin{array}{l}\text { Mandioca na } \\
\text { manteiga } \\
\text { Creme de milho }\end{array}$ & $\begin{array}{l}\text { Purê de batatas } \\
\text { Torta de legumes }\end{array}$ & $\begin{array}{l}\text { Massa à } \\
\text { Romanesca } \\
\text { Farofa de ovos }\end{array}$ & $\begin{array}{l}\text { Couve à mineira } \\
\text { Farofa simples }\end{array}$ \\
\hline ACOMPANHAMENTO & $\begin{array}{l}\text { Arroz branco } \\
\text { Arroz à Estância } \\
\text { Feijão simples }\end{array}$ & $\begin{array}{l}\text { Arroz branco } \\
\text { Feijão simples } \\
\text { Tutu de feijão }\end{array}$ & $\begin{array}{l}\text { Arroz branco } \\
\text { Feijão simples } \\
\text { Feijão Tropeiro }\end{array}$ & $\begin{array}{l}\text { Arroz branco } \\
\text { Arroz integral } \\
\text { Feijão simples }\end{array}$ & $\begin{array}{l}\text { Arroz branco } \\
\text { Arroz Indiano } \\
\text { Feijão preto }\end{array}$ \\
\hline COMPLEMENTO & $\begin{array}{l}\text { Suco: Melancia } \\
\text { Refresco: Maracujá }\end{array}$ & $\begin{array}{l}\text { Suco: Laranja c/ } \\
\text { mamão } \\
\text { Refresco: Uva }\end{array}$ & $\begin{array}{l}\text { Suco: Abacaxi c/ } \\
\text { hortelã } \\
\text { Refresco: } \\
\text { Tangerina }\end{array}$ & $\begin{array}{l}\text { Suco: Maracujá } \\
\text { Refresco: Caju }\end{array}$ & $\begin{array}{l}\text { Suco: Limão } \\
\text { Refresco: Goiaba }\end{array}$ \\
\hline SOBREMESA & $\begin{array}{l}\text { Romeu e Julieta } \\
\text { Pudim de biscoito } \\
\text { Mamão/ Laranja }\end{array}$ & $\begin{array}{l}\text { Creme belga } \\
\text { Curau } \\
\text { Melão/ Abacaxi }\end{array}$ & $\begin{array}{l}\text { Falso brigadeirão } \\
\text { Delicia de Pêssego } \\
\text { Melancia/ Banana }\end{array}$ & $\begin{array}{l}\text { Figos ao creme } \\
\text { Bolo de cenoura } \\
\text { c/ cobertura de } \\
\text { chocolate } \\
\text { Abacaxi/ Melão }\end{array}$ & \begin{tabular}{|l|} 
Flan de côco \\
Gelatina de \\
framboesa \\
Melancia/ Mamão
\end{tabular} \\
\hline
\end{tabular}


Apêndice II

CORAL - Serviços de Refeições Industriais Ltda PERÍODO: 08/07 à 12/07/02

\begin{tabular}{|c|c|c|c|c|c|}
\hline COMPOSIÇÃO & SEG - FEIRA & TER - FEIRA & QUAR - FEIRA & QUIN - FEIRA & SEX - FEIRA \\
\hline ENTRADA & $\begin{array}{l}\text { Salada Carnaval } \\
\text { Alface/ Tomate } \\
\text { Acelga/ Vagem } \\
\text { Cenoura cozida } \\
\text { Melancia }\end{array}$ & $\begin{array}{l}\text { Salada de Batatas } \\
\text { Alface/ Tomate } \\
\text { Agrião/ Chuchu } \\
\text { Beterraba cozida } \\
\text { Melão }\end{array}$ & $\begin{array}{l}\text { Maionese } \\
\text { Tradicional } \\
\text { Alface/ Tomate } \\
\text { Couve/ Cenoura } \\
\text { coz. } \\
\text { Batata doce/ } \\
\text { Abacaxi } \\
\end{array}$ & $\begin{array}{l}\text { Salada Show } \\
\text { Alface/ Tomate } \\
\text { Espinafre/ } \\
\text { Abobrinha } \\
\text { Beterraba cozida } \\
\text { Mamão }\end{array}$ & $\begin{array}{l}\text { Salada } \\
\text { Valênciana } \\
\text { Alface/ Tomate } \\
\text { Rúcula/ Ovo coz. } \\
\text { Cenoura ralada } \\
\text { Laranja }\end{array}$ \\
\hline PRATOS PRINCIPAIS & $\begin{array}{l}\text { Frango surpresa } \\
\text { Bife Argentino } \\
\text { Moela ao molho de } \\
\text { vinho }\end{array}$ & $\begin{array}{l}\text { Frango a } \\
\text { passarinho } \\
\text { Medalhão } \\
\text { Guisado sertanejo }\end{array}$ & $\begin{array}{l}\text { CHURRASCO } \\
\text { Peixe à Barcelona } \\
\text { Strogonoff de } \\
\text { frango }\end{array}$ & $\begin{array}{l}\text { Frango grelhado } \\
\text { Carne assada } \\
\text { Brochete de carne }\end{array}$ & $\begin{array}{l}\text { Rabada com } \\
\text { agrião } \\
\text { Peixe frito } \\
\text { Frango à } \\
\text { caçadora II }\end{array}$ \\
\hline GUARNIÇÕES & $\begin{array}{l}\text { Purê de batatas } \\
\text { Couve-flor ao forno }\end{array}$ & $\begin{array}{l}\text { Suflê de palmito } \\
\text { Farofa Paulista }\end{array}$ & $\begin{array}{l}\text { Batata corada } \\
\text { Brócolis alho e óleo }\end{array}$ & $\begin{array}{l}\text { Banana frita } \\
\text { Nhoque ao sugo }\end{array}$ & $\begin{array}{l}\text { Polenta } \\
\text { Farofa simples }\end{array}$ \\
\hline ACOMPANHAMENTO & $\begin{array}{l}\text { Arroz branco } \\
\text { Arroz latino } \\
\text { Feijão simples }\end{array}$ & $\begin{array}{l}\text { Arroz branco } \\
\text { Arroz integral com } \\
\text { lentilhas } \\
\text { Feijão simples } \\
\end{array}$ & $\begin{array}{l}\text { Arroz branco } \\
\text { Feijão simples } \\
\text { Feijão tropeiro }\end{array}$ & $\begin{array}{l}\text { Arroz branco } \\
\text { Arroz vegetariano } \\
\text { Feijão simples }\end{array}$ & $\begin{array}{l}\text { Arroz branco } \\
\text { Arroz integral } \\
\text { Feijão simples }\end{array}$ \\
\hline COMPLEMENTO & $\begin{array}{l}\text { Suco: Maracujá } \\
\text { Refresco: Acerola }\end{array}$ & $\begin{array}{l}\text { Suco: Abacaxi } \\
\text { Refresco: Uva }\end{array}$ & $\begin{array}{l}\text { Suco: Laranja com } \\
\text { banana } \\
\text { Refresco: } \\
\text { Tamarindo } \\
\end{array}$ & $\begin{array}{l}\text { Suco: Melancia } \\
\text { Refresco: } \\
\text { Tangerina }\end{array}$ & $\begin{array}{l}\text { Suco: Limão } \\
\text { Refresco: Goiaba }\end{array}$ \\
\hline SOBREMESA & $\begin{array}{l}\text { Pêssego ao creme } \\
\text { Creme xadrez } \\
\text { Mamão/ Melão }\end{array}$ & $\begin{array}{l}\text { Rocambole de } \\
\text { doce de leite } \\
\text { Gelatina de } \\
\text { morango } \\
\text { Laranja/ Melancia }\end{array}$ & $\begin{array}{l}\text { Pavê de figo } \\
\text { Doce de abóbora } \\
\text { com coco ralado } \\
\text { Melão/ Mamão }\end{array}$ & $\begin{array}{l}\text { Gelatina de abacaxi } \\
\text { Bolo gelado } \\
\text { Salada de fruta } \\
\text { laranja }\end{array}$ & $\begin{array}{l}\text { Banana } \\
\text { caramelada } \\
\text { Flan de chocolate } \\
\text { Abacaxi/ Melão }\end{array}$ \\
\hline
\end{tabular}


Apêndice III

CORAL - Serviços de Refeições Industriais Ltda PERÍODO: 15/07 à 19/07/02

\begin{tabular}{|c|c|c|c|c|c|}
\hline COMPOSIÇÃO & SEG - FEIRA & TER - FEIRA & QUAR - FEIRA & QUIN - FEIRA & SEX - FEIRA \\
\hline ENTRADA & $\begin{array}{l}\text { Salada Sara } \\
\text { Alface/ Tomate } \\
\text { Tabule/ Agrião } \\
\text { Cenoura cozida } \\
\text { Melão } \\
\end{array}$ & $\begin{array}{l}\text { Maionese básica } \\
\text { Alface/ Tomate } \\
\text { Chicória/ Beterraba } \\
\text { coz./ Repolho roxo } \\
\text { Mamão } \\
\end{array}$ & $\begin{array}{l}\text { Salpicão de frango } \\
\text { Alface/ Tomate } \\
\text { Espinafre/ Chuchu } \\
\text { Cenoura cozida } \\
\text { Abacaxi } \\
\end{array}$ & $\begin{array}{l}\text { Salada Star } \\
\text { Alface/ Tomate } \\
\text { Agrião/ Berinjela } \\
\text { Beterraba cozida } \\
\text { Uva } \\
\end{array}$ & $\begin{array}{l}\text { Salada cremosa } \\
\text { Alface/ Tomate } \\
\text { Acelga/ Chuchu } \\
\text { Cenoura cozida } \\
\text { Laranja } \\
\end{array}$ \\
\hline PRATOS PRINCIPAIS & $\begin{array}{l}\text { Carne moída com } \\
\text { azeitona } \\
\text { Bife a parmegiana } \\
\text { Frango ao caribe } \\
\end{array}$ & $\begin{array}{l}\text { Ensopado Alemão } \\
\text { Fricandole de } \\
\text { frango } \\
\text { Lombo assado }\end{array}$ & $\begin{array}{l}\text { CHURRASCO } \\
\text { Gulash de peixe } \\
\text { Almôndegas ao } \\
\text { sugo }\end{array}$ & $\begin{array}{l}\text { Costela ensopada } \\
\text { Frango na } \\
\text { mostarda } \\
\text { Isca de fígado }\end{array}$ & $\begin{array}{l}\text { Feijoada } \\
\text { Isca de frango à } \\
\text { Lisboete } \\
\text { Peixe à milanesa }\end{array}$ \\
\hline GUARNIÇÕES & \begin{tabular}{|l} 
Batata corada \\
Farofa de ovos
\end{tabular} & $\begin{array}{l}\text { Macarrão alho e } \\
\text { óleo } \\
\text { Berinjela enrolada }\end{array}$ & $\begin{array}{l}\text { Banana frita } \\
\text { Suflê de cenoura }\end{array}$ & $\begin{array}{l}\text { Mandioca cozida } \\
\text { Creme de milho }\end{array}$ & $\begin{array}{l}\text { Couve à mineira } \\
\text { Farofa simples }\end{array}$ \\
\hline ACOMPANHAMENTO & $\begin{array}{l}\text { Arroz branco } \\
\text { Feijão simples } \\
\text { Baião de dois }\end{array}$ & $\begin{array}{l}\text { Arroz branco } \\
\text { Arroz integral } \\
\text { Feijão simples }\end{array}$ & $\begin{array}{l}\text { Arroz branco } \\
\text { Feijão simples } \\
\text { Feijão tropeiro }\end{array}$ & $\begin{array}{l}\text { Arroz branco } \\
\text { Arroz integral } \\
\text { Feijão simples }\end{array}$ & $\begin{array}{l}\text { Arroz branco } \\
\text { Arroz colorido } \\
\text { Feijão preto }\end{array}$ \\
\hline COMPLEMENTO & $\begin{array}{l}\text { Suco: Melancia } \\
\text { Refresco: } \\
\text { Tangerina } \\
\end{array}$ & $\begin{array}{l}\text { Suco: Limão com } \\
\text { cenoura } \\
\text { Refresco: Uva }\end{array}$ & $\begin{array}{l}\text { Suco: Maracujá } \\
\text { Refresco: Acerola }\end{array}$ & $\begin{array}{l}\text { Suco: Abacaxi } \\
\text { Refresco: Goiaba }\end{array}$ & $\begin{array}{l}\text { Suco: Limão } \\
\text { Refresco: } \\
\text { Maracujá } \\
\end{array}$ \\
\hline SOBREMESA & $\begin{array}{l}\text { Frutas ao creme de } \\
\text { côco } \\
\text { Doce de banana } \\
\text { Mamão/ Abacaxi } \\
\end{array}$ & $\begin{array}{l}\text { Curau } \\
\text { Arroz doce } \\
\text { Salada de frutas } \\
\text { Banana }\end{array}$ & $\begin{array}{l}\text { Manjar com ameixa } \\
\text { Gelatina de } \\
\text { morango } \\
\text { Melão/ Mamão } \\
\end{array}$ & $\begin{array}{l}\text { Flocos } \\
\text { Doce de leite com } \\
\text { queijo } \\
\text { Laranja/ Melancia } \\
\end{array}$ & $\begin{array}{l}\text { Creme rosa } \\
\text { Pavê de Pêssego } \\
\text { Abacaxi/ Banana }\end{array}$ \\
\hline
\end{tabular}


Apêndice IV

CORAL - Serviços de Refeições Industriais Ltda PERÍODO: 22/07 à 26/07/02

\begin{tabular}{|c|c|c|c|c|c|}
\hline COMPOSIÇÃO & SEG - FEIRA & TER - FEIRA & QUAR - FEIRA & QUIN - FEIRA & SEX - FEIRA \\
\hline ENTRADA & $\begin{array}{l}\text { Salada Marcos } \\
\text { Alface/ Tomate } \\
\text { Chicória/ Vagem } \\
\text { Beterraba ralada } \\
\text { Abacaxi }\end{array}$ & $\begin{array}{l}\text { Salada Colorida } \\
\text { Alface/ Tomate } \\
\text { Acelga/ Broto de } \\
\text { feijão/ Batata doce } \\
\text { Mamão }\end{array}$ & \begin{tabular}{|l} 
Salada de \\
macarrão \\
Alface/ Tomate \\
Agrião/ Cenoura \\
coz. \\
Pepino/ Laranja
\end{tabular} & $\begin{array}{l}\text { Maionese básica } \\
\text { Alface/ Tomate } \\
\text { Almeirão/ Chuchu } \\
\text { Beterraba cozida } \\
\text { Melão }\end{array}$ & $\begin{array}{l}\text { Maionese } \\
\text { maravilha } \\
\text { Alface/ Tomate } \\
\text { Rúcula/ Ovos } \\
\text { cozidos } \\
\text { Cenoura cozida } \\
\text { Laranja }\end{array}$ \\
\hline PRATOS PRINCIPAIS & \begin{tabular}{|l|} 
Frango chilindrón \\
Carne de sol \\
Picadinho cremoso
\end{tabular} & $\begin{array}{l}\text { Frango a la Kiev } \\
\text { Carne ao brasé } \\
\text { Língua ao molho } \\
\text { rotty }\end{array}$ & \begin{tabular}{|l|} 
CHURRASCO \\
Bife à rolê \\
Frango à caçadora \\
II
\end{tabular} & $\begin{array}{l}\text { Panqueca de } \\
\text { frango } \\
\text { Bife à Diana } \\
\text { Assado vienense }\end{array}$ & $\begin{array}{l}\text { Dobradinha } \\
\text { Frango Holândês } \\
\text { Peixe assado }\end{array}$ \\
\hline GUARNIÇÕES & $\begin{array}{l}\text { Bolo de batata } \\
\text { Legumes diversos }\end{array}$ & \begin{tabular}{|l} 
Couve-flor \\
gratinada \\
Rocambole de \\
espinafre com \\
queijo \\
\end{tabular} & $\begin{array}{l}\text { Purê Argentino } \\
\text { Macarrão alho e } \\
\text { óleo }\end{array}$ & $\begin{array}{l}\text { Croquete de milho } \\
\text { Suflê de cenoura }\end{array}$ & \begin{tabular}{|l|} 
Couve refogada \\
Farofa simples
\end{tabular} \\
\hline ACOMPANHAMENTO & \begin{tabular}{|l} 
Arroz branco \\
Arroz boliviano \\
Feijão simples
\end{tabular} & $\begin{array}{l}\text { Arroz branco } \\
\text { Arroz integral } \\
\text { Feijão simples }\end{array}$ & $\begin{array}{l}\text { Arroz branco } \\
\text { Feijão simples } \\
\text { Feijão tropeiro }\end{array}$ & $\begin{array}{l}\text { Arroz branco } \\
\text { Arroz integral } \\
\text { Feijão simples }\end{array}$ & $\begin{array}{l}\text { Arroz branco } \\
\text { Feijão simples } \\
\text { Feijão preto }\end{array}$ \\
\hline COMPLEMENTO & $\begin{array}{l}\text { Suco: Maracujá } \\
\text { Refresco: Goiaba } \\
\text { com acerola }\end{array}$ & $\begin{array}{l}\text { Suco: Abacaxi } \\
\text { Refresco: Uva }\end{array}$ & $\begin{array}{l}\text { Suco: Melancia } \\
\text { Refresco: } \\
\text { Tangerina } \\
\end{array}$ & $\begin{array}{l}\text { Suco: Laranja } \\
\text { Refresco: } \\
\text { Tamarindo } \\
\end{array}$ & $\begin{array}{l}\text { Suco: Limão } \\
\text { Refresco: } \\
\text { Maracujá }\end{array}$ \\
\hline SOBREMESA & $\begin{array}{l}\text { Doce de banana } \\
\text { Gelatina de uva } \\
\text { Mamão/ Melão }\end{array}$ & $\begin{array}{l}\text { Pudim de queijo } \\
\text { Flan de chocolate } \\
\text { com coco ralado } \\
\text { Melancia/ Laranja }\end{array}$ & $\begin{array}{l}\text { Gelatina de cereja } \\
\text { Delícia de pêssego } \\
\text { Melão/ Abacaxi }\end{array}$ & $\begin{array}{l}\text { Doce de leite } \\
\text { cremoso } \\
\text { Pudim bicolor } \\
\text { Salada de frutas } \\
\text { Mamão }\end{array}$ & $\begin{array}{l}\text { Pavê de chocolate } \\
\text { Gelatina colorida } \\
\text { Melancia/ Abacaxi }\end{array}$ \\
\hline
\end{tabular}


Apêndice V

CORAL - Serviços de Refeições Industriais Ltda PERÍODO: 29/07 à 02/08/02

\begin{tabular}{|c|c|c|c|c|c|}
\hline COMPOSIÇÃO & SEG - FEIRA & TER - FEIRA & QUAR - FEIRA & QUIN - FEIRA & SEX - FEIRA \\
\hline ENTRADA & $\begin{array}{l}\text { Salada Nice } \\
\text { Alface/ Tomate } \\
\text { Agrião/ Cenoura } \\
\text { ral. } \\
\text { Chuchu/ Mamão }\end{array}$ & $\begin{array}{l}\text { Torta fria } \\
\text { Alface/ Tomate } \\
\text { Acelga/ Pepino } \\
\text { Abóbora/ Abacaxi }\end{array}$ & \begin{tabular}{|l|} 
Salada mista II \\
Alface/ Tomate \\
Repolho/ \\
Mostarda \\
Beterraba cozida \\
Melão \\
\end{tabular} & $\begin{array}{l}\text { Salada Imperial } \\
\text { Alface/ Tomate } \\
\text { Abobrinha/ Rúcula } \\
\text { Beterraba ralada } \\
\text { Melancia }\end{array}$ & $\begin{array}{l}\text { Salada Mimosa } \\
\text { Alface/ Tomate } \\
\text { Cenoura ralada } \\
\text { Espinafre/ Batata } \\
\text { doce/ Laranja }\end{array}$ \\
\hline PRATOS PRINCIPAIS & $\begin{array}{l}\text { Frango à } \\
\text { passarinho } \\
\text { Brochete de carne } \\
\text { Almôndegas }\end{array}$ & $\begin{array}{l}\text { Strogonoff de frango } \\
\text { Escalopinho ao } \\
\text { molho madeira } \\
\text { Carne ao brasé }\end{array}$ & $\begin{array}{l}\text { CHURRASCO } \\
\text { Peixe à Itamaraty } \\
\text { Frango na coca- } \\
\text { cola }\end{array}$ & $\begin{array}{l}\text { Chester à } \\
\text { califórnia } \\
\text { Picadinho } \\
\text { especial } \\
\text { Bisteca grelhada }\end{array}$ & $\begin{array}{l}\text { Feijoada } \\
\text { Peixe à baiana } \\
\text { madalena }\end{array}$ \\
\hline GUARNIÇÕES & $\begin{array}{l}\text { Couve-flor } \\
\text { gratinada } \\
\text { Macarrão à } \\
\text { carbonana }\end{array}$ & $\begin{array}{l}\text { Batata frita } \\
\text { Creme de milho }\end{array}$ & $\begin{array}{l}\text { Cenoura e vagem } \\
\text { sautê } \\
\text { Pizza vegetariana }\end{array}$ & $\begin{array}{l}\text { Suflê de palmito } \\
\text { Quibebe de } \\
\text { mandioca }\end{array}$ & $\begin{array}{l}\text { Farofa simples } \\
\text { Couve à mineira }\end{array}$ \\
\hline ACOMPANHAMENTO & $\begin{array}{l}\text { Arroz branco } \\
\text { Arroz com brócolis } \\
\text { Feijão simples }\end{array}$ & $\begin{array}{l}\text { Arroz banco } \\
\text { Arroz Napolitano } \\
\text { Feijão simples }\end{array}$ & $\begin{array}{l}\text { Arroz branco } \\
\text { Arroz integral } \\
\text { Feijão simples }\end{array}$ & $\begin{array}{l}\text { Arroz branco } \\
\text { Arroz à grega } \\
\text { Feijão simples }\end{array}$ & $\begin{array}{l}\text { Arroz branco } \\
\text { Arroz integral } \\
\text { Feijão simples }\end{array}$ \\
\hline COMPLEMENTO & $\begin{array}{l}\text { Suco: Limão com } \\
\text { cenoura } \\
\text { Refresco: Goiaba } \\
\end{array}$ & $\begin{array}{l}\text { Suco: Laranja } \\
\text { Refresco: Uva }\end{array}$ & $\begin{array}{l}\text { Suco: Maracujá } \\
\text { Refresco: Caju }\end{array}$ & $\begin{array}{l}\text { Suco: Abacaxi c/ } \\
\text { hortelã } \\
\text { Refresco: Acerola } \\
\end{array}$ & $\begin{array}{l}\text { Suco: Limão } \\
\text { Refresco: } \\
\text { Tangerina } \\
\end{array}$ \\
\hline SOBREMESA & $\begin{array}{l}\text { Delícia de pêssego } \\
\text { Gelatina de } \\
\text { Morango } \\
\text { Abacaxi/ Melão }\end{array}$ & $\begin{array}{l}\text { Bolo de cenoura cl } \\
\text { cobertura de } \\
\text { chocolate } \\
\text { Maravilha de limão } \\
\text { Mamão/ Banana } \\
\end{array}$ & $\begin{array}{l}\text { Doce de leite } \\
\text { Pudim de biscoito } \\
\text { Laranja/ Melancia }\end{array}$ & $\begin{array}{l}\text { Bolo quequel } \\
\text { Neve de laranja } \\
\text { Melão/ Mamão }\end{array}$ & $\begin{array}{l}\text { Flan de côco com } \\
\text { cobertura de } \\
\text { chocolate } \\
\text { Gelatina de uva } \\
\text { Banana/ Abacaxi }\end{array}$ \\
\hline
\end{tabular}


Apêndice VI

CORAL - Serviços de Refeições Industriais Ltda PERÍODO: 05/08 à 09/08/02

\begin{tabular}{|c|c|c|c|c|c|}
\hline COMPOSIÇÃO & SEG - FEIRA & TER - FEIRA & QUAR - FEIRA & QUIN - FEIRA & SEX - FEIRA \\
\hline ENTRADA & $\begin{array}{l}\text { Salada Pabo } \\
\text { Alface/ Tomate } \\
\text { Acelga/ Repolho } \\
\text { Beterraba cozida } \\
\text { Mamão }\end{array}$ & $\begin{array}{l}\text { Salpicão de frango } \\
\text { Alface/ Tomate } \\
\text { Tabule/ Cenoura } \\
\text { coz. } \\
\text { Abobrinha/ Laranja }\end{array}$ & $\begin{array}{l}\text { Salada dos Sonhos } \\
\text { Alface/ Tomate } \\
\text { Agrião/Beterraba } \\
\text { coz. } \\
\text { Vagem/ Melão }\end{array}$ & $\begin{array}{l}\text { Salada Ami } \\
\text { Alface/ Tomate } \\
\text { Chicória/ Berinjela } \\
\text { Chuchu/ Melancia }\end{array}$ & \begin{tabular}{|l|} 
Grão-de-bico \\
especial \\
Alface/ Tomate \\
Beterraba cozida \\
Rabanete/ Cenoura \\
ralada/ Laranja \\
\end{tabular} \\
\hline PRATOS PRINCIPAIS & $\begin{array}{l}\text { Frango Holandês } \\
\text { Cupim assado } \\
\text { Isca de carne } \\
\text { acebolada }\end{array}$ & $\begin{array}{l}\text { Strogonoff de carne } \\
\text { Bife Rossini } \\
\text { Frango à milanesa }\end{array}$ & $\begin{array}{l}\text { CHURRASCO } \\
\text { Vatapá de peixe } \\
\text { Omelete campestre }\end{array}$ & $\begin{array}{l}\text { Lombo assado } \\
\text { com abacaxi } \\
\text { Frango grelhado } \\
\text { Picadinho } \\
\text { especial }\end{array}$ & $\begin{array}{l}\text { Feijoada } \\
\text { Frango tropical } \\
\text { Peixe grelhado }\end{array}$ \\
\hline GUARNIÇÕES & $\begin{array}{l}\text { Nhoque ao sugo } \\
\text { Farofa de passas } \\
\text { com bacon }\end{array}$ & $\begin{array}{l}\text { Batata corada } \\
\text { Charuto } \\
\text { vegetariano }\end{array}$ & $\begin{array}{l}\text { Suflê de espinafre } \\
\text { e queijo } \\
\text { Banana frita }\end{array}$ & $\begin{array}{l}\text { Purê de mandioca } \\
\text { Macarrão ao sugo }\end{array}$ & $\begin{array}{l}\text { Couve à mineira } \\
\text { Farofa simples }\end{array}$ \\
\hline ACOMPANHAMENTO & $\begin{array}{l}\text { Arroz branco } \\
\text { Feijão simples } \\
\text { Feijão preto }\end{array}$ & $\begin{array}{l}\text { Arroz branco } \\
\text { Arroz com brócolis } \\
\text { Feijão simples }\end{array}$ & $\begin{array}{l}\text { Arroz branco } \\
\text { Arroz integral } \\
\text { Feijão simples }\end{array}$ & $\begin{array}{l}\text { Arroz branco } \\
\text { Arroz colorido } \\
\text { Feijão simples }\end{array}$ & $\begin{array}{l}\text { Arroz branco } \\
\text { Arroz integral } \\
\text { Feijão preto }\end{array}$ \\
\hline COMPLEMENTO & $\begin{array}{l}\text { Suco: Abacaxi } \\
\text { Refresco: } \\
\text { Tangerina } \\
\end{array}$ & $\begin{array}{l}\text { Suco: Maracujá } \\
\text { Refresco: Caju }\end{array}$ & $\begin{array}{l}\text { Suco: Limão } \\
\text { Refresco: Acerola }\end{array}$ & $\begin{array}{l}\text { Suco: Coquetel de } \\
\text { frutas } \\
\text { Refresco: Abacaxi } \\
\end{array}$ & $\begin{array}{l}\text { Suco: Limão } \\
\text { Refresco: Uva }\end{array}$ \\
\hline SOBREMESA & $\begin{array}{l}\text { Pêssego espelhado } \\
\text { Brigadeirão } \\
\text { Melão/ Banana }\end{array}$ & $\begin{array}{l}\text { Delícia de abacaxi } \\
\text { Banana } \\
\text { caramelada } \\
\text { Mamão/ Melancia }\end{array}$ & $\begin{array}{l}\text { Gelatina de } \\
\text { framboesa } \\
\text { Creme xadrez } \\
\text { Abacaxi } \\
\text { Salada de frutas }\end{array}$ & $\begin{array}{l}\text { Pudim de leite } \\
\text { Creme de côco } \\
\text { Melão/ Banana }\end{array}$ & $\begin{array}{l}\text { Flan de morango } \\
\text { com cereja } \\
\text { Gelatina de uva } \\
\text { Melancia/ Mamão }\end{array}$ \\
\hline
\end{tabular}


Apêndice VII

CORAL - Serviços de Refeições IndustriaisLtda PERÍODO: 12/08 à16/08/02

\begin{tabular}{|c|c|c|c|c|c|}
\hline COMPOSIÇÃO & SEG - FEIRA & TER - FEIRA & QUAR - FEIRA & QUIN - FEIRA & SEX - FEIRA \\
\hline ENTRADA & $\begin{array}{l}\text { Salada Samira } \\
\text { Alface/ Tomate } \\
\text { Espinafre/ } \\
\text { Beterraba ralada } \\
\text { /Abobrinha } \\
\text { Uva }\end{array}$ & $\begin{array}{l}\text { Salada Suíça } \\
\text { Alface/ Tomate } \\
\text { Acelga/ Tabule } \\
\text { Vagem/ Melancia }\end{array}$ & \begin{tabular}{|l|} 
Salada de \\
Cenouras \\
Alface/ Tomate \\
Agrião/ Batata doce \\
Maxixe/ Abacaxi
\end{tabular} & $\begin{array}{l}\text { Salada Waldorf } \\
\text { Alface/ Tomate } \\
\text { Chicória/ Repolho } \\
\text { roxo/ Abobrinha } \\
\text { Mamão }\end{array}$ & $\begin{array}{l}\text { Salada Russa } \\
\text { Alface/ Tomate } \\
\text { Rabanete/ Pepino } \\
\text { Chuchu/ Laranja }\end{array}$ \\
\hline PRATOS PRINCIPAIS & $\begin{array}{l}\text { Frango na laranja } \\
\text { Carne com batata } \\
\text { baroa } \\
\text { Escalopinho ao } \\
\text { molho madeira } \\
\end{array}$ & $\begin{array}{l}\text { Frango grelhado } \\
\text { Bife rolê } \\
\text { Cupim assado }\end{array}$ & $\begin{array}{l}\text { CHURRASCO } \\
\text { Peixe ao molho de } \\
\text { camarão } \\
\text { Ovo frito }\end{array}$ & $\begin{array}{l}\text { Fricassé de } \\
\text { frango } \\
\text { Pernil agridoce } \\
\text { Carne moída com } \\
\text { azeitona } \\
\end{array}$ & $\begin{array}{l}\text { Feijoada } \\
\text { Peixe à Dorê } \\
\text { Frango na coca- } \\
\text { cola }\end{array}$ \\
\hline GUARNIÇÕES & $\begin{array}{l}\text { Creme de milho } \\
\text { Berinjela recheada }\end{array}$ & $\begin{array}{l}\text { Purê Argentino } \\
\text { Farofa de passas }\end{array}$ & $\begin{array}{l}\text { Batata Portuguesa } \\
\text { Bolinho de aipim } \\
\text { recheado }\end{array}$ & $\begin{array}{l}\text { Espaguete à } \\
\text { Francesa } \\
\text { Legumes verdes }\end{array}$ & $\begin{array}{l}\text { Couve à mineira } \\
\text { Farofa simples }\end{array}$ \\
\hline ACOMPANHAMENTO & $\begin{array}{l}\text { Arroz branco } \\
\text { Arroz à Princesa } \\
\text { Feijão simples }\end{array}$ & $\begin{array}{l}\text { Arroz branco } \\
\text { Arroz integral } \\
\text { Feijão simples }\end{array}$ & $\begin{array}{l}\text { Arroz branco } \\
\text { Feijão simples } \\
\text { Feijão Tropeiro }\end{array}$ & $\begin{array}{l}\text { Arroz branco } \\
\text { Arroz integral } \\
\text { Feijão simples }\end{array}$ & $\begin{array}{l}\text { Arroz branco } \\
\text { Feijão simples } \\
\text { Feijão preto }\end{array}$ \\
\hline COMPLEMENTO & $\begin{array}{l}\text { Suco: Maracujá } \\
\text { Refresco: Uva }\end{array}$ & $\begin{array}{l}\text { Suco: Abacaxi } \\
\text { Refresco: } \\
\text { Tamarindo } \\
\end{array}$ & $\begin{array}{l}\text { Suco: Coquetel de } \\
\text { frutas } \\
\text { Refresco: Acerola }\end{array}$ & $\begin{array}{l}\text { Suco: Melancia } \\
\text { Refresco: Caju }\end{array}$ & $\begin{array}{l}\text { Suco: Limão } \\
\text { Refresco: } \\
\text { Tangerina } \\
\end{array}$ \\
\hline SOBREMESA & $\begin{array}{l}\text { Pudim bicolor } \\
\text { Creme de ameixa } \\
\text { Abacaxi/ Mamão }\end{array}$ & $\begin{array}{l}\text { Curau } \\
\text { Manjar com ameixa } \\
\text { Melão/ Laranja }\end{array}$ & $\begin{array}{l}\text { Gelatina colorida } \\
\text { Pavê simples } \\
\text { Banana/ Melancia }\end{array}$ & $\begin{array}{l}\text { Bolo de chocolate } \\
\text { Pêssego ao } \\
\text { creme de baunilha } \\
\text { Abacaxi/ Melão } \\
\end{array}$ & \begin{tabular}{|l|} 
Gelatina de \\
morango \\
Pudim de maracujá \\
Mamão/ Melancia \\
\end{tabular} \\
\hline
\end{tabular}


Apêndice VIII

CORAL - Serviços de Refeições Industriais Ltda PERÍODO: 19/08 à 23/08/02

\begin{tabular}{|c|c|c|c|c|c|}
\hline COMPOSIÇÃO & SEG - FEIRA & TER - FEIRA & QUAR - FEIRA & QUIN - FEIRA & SEX - FEIRA \\
\hline ENTRADA & $\begin{array}{l}\text { Salada Camponesa } \\
\text { Alface/ Tomate } \\
\text { Lentilha/ Abobrinha } \\
\text { Acelga/ Mamão }\end{array}$ & \begin{tabular}{|l|} 
Salada Original \\
Alface/ Tomate \\
Chicória/ Cenoura \\
coz./ Abóbora \\
Melão \\
\end{tabular} & $\begin{array}{l}\text { Salada Siciliana } \\
\text { Alface/ Tomate } \\
\text { Chuchu/ Agrião } \\
\text { Beterraba cozida } \\
\text { Melancia } \\
\end{array}$ & $\begin{array}{l}\text { Salada Marília } \\
\text { Alface/ Tomate } \\
\text { Rúcula/ broto de } \\
\text { feijão/ Beterraba } \\
\text { crua/ Abacaxi } \\
\end{array}$ & $\begin{array}{l}\text { Taça de legumes } \\
\text { Alface/ Tomate } \\
\text { Acelga/ Beterraba } \\
\text { coz./ Cenoura crua } \\
\text { Laranja } \\
\end{array}$ \\
\hline PRATOS PRINCIPAIS & $\begin{array}{l}\text { Frango à romana } \\
\text { Fricandole de carne } \\
\text { Cozido com } \\
\text { legumes }\end{array}$ & $\begin{array}{l}\text { Frango ao molho } \\
\text { de açafrão } \\
\text { Lagarto recheado } \\
\text { Isca de lombo à } \\
\text { campanha }\end{array}$ & $\begin{array}{l}\text { CHURRASCO } \\
\text { Peixe assado } \\
\text { Omelete de queijo }\end{array}$ & $\begin{array}{l}\text { Bife acebolado } \\
\text { Frango surpresa } \\
\text { Carne moída com } \\
\text { azeitona }\end{array}$ & $\begin{array}{l}\text { Rabada com agrião } \\
\text { Peixe à dorê } \\
\text { Frango à chilindrón }\end{array}$ \\
\hline GUARNIÇÕES & $\begin{array}{l}\text { Lasanha de milho } \\
\text { Couve-flor à dorê }\end{array}$ & $\begin{array}{l}\text { Quiabo refogado } \\
\text { Farofa de ovo }\end{array}$ & \begin{tabular}{|l|} 
Milho verde \\
especial \\
Macarrão alho e \\
óleo
\end{tabular} & $\begin{array}{l}\text { Mandioca cozida } \\
\text { Suflê de chuchu }\end{array}$ & $\begin{array}{l}\text { Polenta } \\
\text { Farofa simples }\end{array}$ \\
\hline ACOMPANHAMENTO & $\begin{array}{l}\text { Arroz branco } \\
\text { Arroz à grega } \\
\text { Feijão simples }\end{array}$ & $\begin{array}{l}\text { Arroz branco } \\
\text { Arroz integral } \\
\text { Feijão simples }\end{array}$ & $\begin{array}{l}\text { Arroz branco } \\
\text { Feijão simples } \\
\text { Feijão tropeiro }\end{array}$ & $\begin{array}{l}\text { Arroz branco } \\
\text { Arroz integral } \\
\text { Feijão simples }\end{array}$ & $\begin{array}{l}\text { Arroz branco } \\
\text { Feijão simples } \\
\text { Feijão preto }\end{array}$ \\
\hline COMPLEMENTO & $\begin{array}{l}\text { Suco: Maracujá } \\
\text { Refresco: Caju }\end{array}$ & $\begin{array}{l}\text { Suco: Laranja } \\
\text { Refresco: Goiaba }\end{array}$ & $\begin{array}{l}\text { Suco: Abacaxi } \\
\text { Refresco: } \\
\text { Tangerina } \\
\text { c/ mamão } \\
\end{array}$ & $\begin{array}{l}\text { Suco: Melancia } \\
\text { Refresco: Laranja }\end{array}$ & $\begin{array}{l}\text { Suco: Limão } \\
\text { Refresco: Uva }\end{array}$ \\
\hline SOBREMESA & $\begin{array}{l}\text { Gelatina de limão } \\
\text { Arroz doce } \\
\text { Melancia/ Laranja }\end{array}$ & $\begin{array}{l}\text { Danete } \\
\text { Flan de côco } \\
\text { Abacaxi/ Mamão }\end{array}$ & $\begin{array}{l}\text { Pudim de chocolate } \\
\text { Rocombole de } \\
\text { doce de leite c/ } \\
\text { ameixa } \\
\text { Laranja/ Melão }\end{array}$ & $\begin{array}{l}\text { Creme xadrez } \\
\text { Banana } \\
\text { caramelada } \\
\text { Salada de frutas } \\
\text { Mamão }\end{array}$ & $\begin{array}{l}\text { Mané pelado } \\
\text { Gelatina fantasia } \\
\text { Banana/ Melancia }\end{array}$ \\
\hline
\end{tabular}


Apêndice IX

CORAL - Servicos de Refeicões Industriais Ltda PERÍODO: 01/07 à 05/07/02

\begin{tabular}{|c|c|c|c|c|c|}
\hline COMPOSIÇÃO & SEG - FEIRA & TER - FEIRA & QUAR - FEIRA & QUIN - FEIRA & SEX - FEIRA \\
\hline ENTRADA & \begin{tabular}{|l|} 
Salada de \\
Macarrão \\
Alface/ Tomate \\
Chicória/ Vagem \\
Beterraba ralada \\
Abacaxi \\
\end{tabular} & \begin{tabular}{|l} 
Salpicão \\
Vegetariano \\
Alface/ Tomate \\
Agrião/ Chuchu \\
Picles/ Melancia
\end{tabular} & $\begin{array}{l}\text { Salada Primavera } \\
\text { Alface/ Tomate } \\
\text { Acelga/ Cenoura } \\
\text { coz. } \\
\text { Maxixe/ Mamão }\end{array}$ & $\begin{array}{l}\text { Torta fria } \\
\text { Alface/ Tomate } \\
\text { Beterraba coz. } \\
\text { Abóbora / Rúcula } \\
\text { Uva }\end{array}$ & $\begin{array}{l}\text { Salada Coral } \\
\text { Alface/ Tomate } \\
\text { Espinafre/ } \\
\text { Abobrinha } \\
\text { Cenoura ralada } \\
\text { Laranja } \\
\end{array}$ \\
\hline PRATOS PRINCIPAIS & $\begin{array}{l}\text { Frango crocante } \\
\text { Bife à Rossini } \\
\text { Lagarto recheado }\end{array}$ & $\begin{array}{l}\text { Rocambole de } \\
\text { frango } \\
\text { Bourguignon } \\
\text { Bisteca grelhada }\end{array}$ & $\begin{array}{l}\text { CHURRASCO } \\
\text { Carne moída com } \\
\text { azeitona } \\
\text { Peixe à Barcelona }\end{array}$ & $\begin{array}{l}\text { Frango à dorê } \\
\text { Tornedor ao } \\
\text { molho Rotty } \\
\text { Almôndega } \\
\text { recheada } \\
\end{array}$ & $\begin{array}{l}\text { Feijoada } \\
\text { Bife acebolado } \\
\text { Enroladinho de } \\
\text { peixe }\end{array}$ \\
\hline GUARNIÇÕES & $\begin{array}{l}\text { Farofa com passas } \\
\text { Batata ao forno }\end{array}$ & $\begin{array}{l}\text { Mandioca na } \\
\text { manteiga } \\
\text { Creme de milho }\end{array}$ & $\begin{array}{l}\text { Purê de abóbora } \\
\text { Torta de legumes }\end{array}$ & \begin{tabular}{|l|} 
Massa à \\
Romanesca \\
Berinjela \\
recheada
\end{tabular} & $\begin{array}{l}\text { Couve à mineira } \\
\text { Farofa simples }\end{array}$ \\
\hline ACOMPANHAMENTO & $\begin{array}{l}\text { Arroz branco } \\
\text { Arroz integral } \\
\text { Feijão simples }\end{array}$ & \begin{tabular}{|l} 
Arroz branco \\
Feijão simples \\
Tutu de feijão
\end{tabular} & $\begin{array}{l}\text { Arroz branco } \\
\text { Feijão simples } \\
\text { Feijão Tropeiro }\end{array}$ & $\begin{array}{l}\text { Arroz branco } \\
\text { Arroz integral } \\
\text { Feijão simples }\end{array}$ & $\begin{array}{l}\text { Arroz branco } \\
\text { Arroz Indiano } \\
\text { Feijão simples }\end{array}$ \\
\hline COMPLEMENTO & $\begin{array}{l}\text { Suco: Melancia } \\
\text { Refresco: Maracujá }\end{array}$ & $\begin{array}{l}\text { Suco: Laranja c/ } \\
\text { mamão } \\
\text { Refresco: Uva }\end{array}$ & $\begin{array}{l}\text { Suco: Abacaxi c/ } \\
\text { hortelã } \\
\text { Refresco: } \\
\text { Tangerina }\end{array}$ & $\begin{array}{l}\text { Suco: Maracujá } \\
\text { Refresco: Caju }\end{array}$ & $\begin{array}{l}\text { Suco: Limão } \\
\text { Refresco: Goiaba }\end{array}$ \\
\hline SOBREMESA & $\begin{array}{l}\text { Romeu e Julieta } \\
\text { Pudim de biscoito } \\
\text { Mamão/ Banana }\end{array}$ & $\begin{array}{l}\text { Creme belga } \\
\text { Manjar } \\
\text { Melão/ Melancia }\end{array}$ & $\begin{array}{l}\text { Falso brigadeirão } \\
\text { Delicia de Pêssego } \\
\text { Laranja } \\
\text { Salada de frutas } \\
\end{array}$ & $\begin{array}{l}\text { Figos ao creme } \\
\text { Bolo de cenoura } \\
\text { Abacaxi/ Melancia }\end{array}$ & $\begin{array}{l}\text { Flan de côco } \\
\text { Gelatina de } \\
\text { framboesa } \\
\text { Melancia/ Mamão }\end{array}$ \\
\hline
\end{tabular}


Apêndice $X$

CORAL - Serviços de Refeições Industriais Ltda PERÍODO: 08/07 à 12/07/02

\begin{tabular}{|c|c|c|c|c|c|}
\hline COMPOSIÇÃO & SEG - FEIRA & TER - FEIRA & QUAR - FEIRA & QUIN - FEIRA & SEX - FEIRA \\
\hline ENTRADA & $\begin{array}{l}\text { Salada Carnaval } \\
\text { Alface/ Tomate } \\
\text { Acelga/ Vagem } \\
\text { Cenoura cozida } \\
\text { Uva }\end{array}$ & $\begin{array}{l}\text { Salada de Batatas } \\
\text { Alface/ Tomate } \\
\text { Agrião/ Chuchu } \\
\text { Beterraba ralada } \\
\text { Melão }\end{array}$ & $\begin{array}{l}\text { Maionese } \\
\text { Tradicional } \\
\text { Alface/ Tomate } \\
\text { Couve/ Cenoura } \\
\text { ral. } \\
\text { Batata doce/ } \\
\text { Abacaxi }\end{array}$ & $\begin{array}{l}\text { Salada Show } \\
\text { Alface/ Tomate } \\
\text { Mostarda/ } \\
\text { Abobrinha } \\
\text { Beterraba ralada } \\
\text { Mamão }\end{array}$ & \begin{tabular}{|l} 
Salada \\
Valênciana \\
Alface/ Tomate \\
Rúcula/ Ovo coz. \\
Cenoura ralada \\
Laranja
\end{tabular} \\
\hline PRATOS PRINCIPAIS & $\begin{array}{l}\text { Frango surpresa } \\
\text { Bife Argentino } \\
\text { Moela ao molho de } \\
\text { vinho }\end{array}$ & \begin{tabular}{|l|} 
Frango a \\
passarinho \\
Medalhão \\
Guisado sertanejo
\end{tabular} & $\begin{array}{l}\text { Bife acebolado } \\
\text { Peixe à Barcelona } \\
\text { Strogonoff de } \\
\text { frango }\end{array}$ & $\begin{array}{l}\text { Frango grelhado } \\
\text { Carne assada } \\
\text { Carne Mexicana }\end{array}$ & $\begin{array}{l}\text { Rabada com } \\
\text { agrião } \\
\text { Peixe frito } \\
\text { Frango à } \\
\text { caçadora II }\end{array}$ \\
\hline GUARNIÇÕES & $\begin{array}{l}\text { Torta Praiana } \\
\text { Couve-flor } \\
\text { gratinada }\end{array}$ & $\begin{array}{l}\text { Suflê de cenoura } \\
\text { Farofa Paulista }\end{array}$ & \begin{tabular}{|l} 
Batata corada \\
Brócolis alho e óleo
\end{tabular} & \begin{tabular}{|l|} 
Banana frita \\
Nhoque ao sugo
\end{tabular} & $\begin{array}{l}\text { Polenta } \\
\text { Farofa simples }\end{array}$ \\
\hline ACOMPANHAMENTO & $\begin{array}{l}\text { Arroz branco } \\
\text { Arroz latino } \\
\text { Feijão simples }\end{array}$ & $\begin{array}{l}\text { Arroz branco } \\
\text { Arroz integral com } \\
\text { lentilhas } \\
\text { Feijão simples }\end{array}$ & $\begin{array}{l}\text { Arroz branco } \\
\text { Arroz à grega } \\
\text { Feijão simples }\end{array}$ & $\begin{array}{l}\text { Arroz branco } \\
\text { Arroz vegetariano } \\
\text { Feijão simples }\end{array}$ & $\begin{array}{l}\text { Arroz branco } \\
\text { Arroz integral } \\
\text { Feijão simples }\end{array}$ \\
\hline COMPLEMENTO & $\begin{array}{l}\text { Suco: Melancia } \\
\text { Refresco: } \\
\text { Tangerina }\end{array}$ & $\begin{array}{l}\text { Suco: Maracujá } \\
\text { Refresco: Caju }\end{array}$ & $\begin{array}{l}\text { Suco: Laranja com } \\
\text { banana } \\
\text { Refresco: } \\
\text { Tamarindo }\end{array}$ & $\begin{array}{l}\text { Suco: Abacaxi } \\
\text { Refresco: Uva }\end{array}$ & $\begin{array}{l}\text { Suco: Limão } \\
\text { Refresco: Goiaba }\end{array}$ \\
\hline SOBREMESA & $\begin{array}{l}\text { Pêssego ao creme } \\
\text { Creme xadrez } \\
\text { Mamão/ Melão }\end{array}$ & \begin{tabular}{|l} 
Rocombole de \\
doce de leite \\
Gelatina de \\
morango \\
Abacaxi/ Melancia \\
\end{tabular} & $\begin{array}{l}\text { Pavê de figo } \\
\text { Doce de abóbora } \\
\text { com coco ralado } \\
\text { Melão/ Mamão }\end{array}$ & $\begin{array}{l}\text { Gelatina de Cereja } \\
\text { Bolo gelado } \\
\text { Melancia/ Laranja }\end{array}$ & \begin{tabular}{|l} 
Banana \\
caramelada \\
Flan de chocolate \\
Abacaxi/ Melão
\end{tabular} \\
\hline
\end{tabular}


Apêndice XI

CORAL - Serviços de Refeições Industriais Ltda PERÍODO: 15/07 à 19/07/02

\begin{tabular}{|c|c|c|c|c|c|}
\hline COMPOSIÇÃO & SEG - FEIRA & TER - FEIRA & QUAR - FEIRA & QUIN - FEIRA & SEX - FEIRA \\
\hline ENTRADA & $\begin{array}{l}\text { Salada Sara } \\
\text { Alface/ Tomate } \\
\text { Tabule/ Agrião } \\
\text { Cenoura ralada } \\
\text { Melão } \\
\end{array}$ & $\begin{array}{l}\text { Maionese básica } \\
\text { Alface/ Tomate } \\
\text { Chicória/ Beterraba } \\
\text { coz./ Repolho roxo } \\
\text { Mamão } \\
\end{array}$ & $\begin{array}{l}\text { Salpicão de frango } \\
\text { Alface/ Tomate } \\
\text { Rúcula/ Chuchu } \\
\text { Cenoura cozida } \\
\text { Abacaxi } \\
\end{array}$ & $\begin{array}{l}\text { Salada Star } \\
\text { Alface/ Tomate } \\
\text { Mostarda/ Batata } \\
\text { doce/Beterraba ral. } \\
\text { Uva } \\
\end{array}$ & $\begin{array}{l}\text { Salada cremosa } \\
\text { Alface/ Tomate } \\
\text { Acelga/ Chuchu } \\
\text { Cenoura ralada } \\
\text { Laranja } \\
\end{array}$ \\
\hline PRATOS PRINCIPAIS & $\begin{array}{l}\text { Silveirinha } \\
\text { Bife a parmegiana } \\
\text { Frango ao caribe }\end{array}$ & $\begin{array}{l}\text { Ensopado Alemão } \\
\text { Fricandole de } \\
\text { frango } \\
\text { Lombo assado }\end{array}$ & $\begin{array}{l}\text { CHURRASCO } \\
\text { Gulash de peixe } \\
\text { Omelete de queijo } \\
\text { c/ espinafre } \\
\end{array}$ & $\begin{array}{l}\text { Costela ensopada } \\
\text { Frango na } \\
\text { mostarda } \\
\text { Isca de fígado } \\
\end{array}$ & $\begin{array}{l}\text { Feijoada } \\
\text { Isca de frango } \\
\text { Peixe à milanesa }\end{array}$ \\
\hline GUARNIÇÕES & $\begin{array}{l}\text { Purê de batata } \\
\text { Farofa de ovos }\end{array}$ & $\begin{array}{l}\text { Macarrão alho e } \\
\text { óleo } \\
\text { Berinjela à dorê }\end{array}$ & $\begin{array}{l}\text { Banana frita } \\
\text { Suflê de palmito }\end{array}$ & $\begin{array}{l}\text { Mandioca cozida } \\
\text { Milho verde } \\
\text { especial }\end{array}$ & $\begin{array}{l}\text { Couve à mineira } \\
\text { Farofa simples }\end{array}$ \\
\hline ACOMPANHAMENTO & $\begin{array}{l}\text { Arroz branco } \\
\text { Feijão simples } \\
\text { Baião de dois }\end{array}$ & $\begin{array}{l}\text { Arroz branco } \\
\text { Arroz integral } \\
\text { Feijão simples }\end{array}$ & $\begin{array}{l}\text { Arroz branco } \\
\text { Feijão simples } \\
\text { Feijão tropeiro }\end{array}$ & $\begin{array}{l}\text { Arroz branco } \\
\text { Arroz integral } \\
\text { Feijão simples }\end{array}$ & $\begin{array}{l}\text { Arroz branco } \\
\text { Arroz colorido } \\
\text { Feijão simples }\end{array}$ \\
\hline COMPLEMENTO & $\begin{array}{l}\text { Suco: Melancia } \\
\text { Refresco: } \\
\text { Tangerina } \\
\end{array}$ & $\begin{array}{l}\text { Suco: Laranja } \\
\text { Refresco: Caju }\end{array}$ & $\begin{array}{l}\text { Suco: Maracujá } \\
\text { Refresco: Acerola }\end{array}$ & $\begin{array}{l}\text { Suco: Abacaxi } \\
\text { Refresco: Goiaba }\end{array}$ & $\begin{array}{l}\text { Suco: Limão } \\
\text { Refresco: Uva }\end{array}$ \\
\hline SOBREMESA & $\begin{array}{l}\text { Frutas ao creme de } \\
\text { côco } \\
\text { Doce de banana } \\
\text { Mamão/ Abacaxi }\end{array}$ & $\begin{array}{l}\text { Curau } \\
\text { Arroz doce } \\
\text { Salada de frutas } \\
\text { Banana }\end{array}$ & $\begin{array}{l}\text { Manjar com ameixa } \\
\text { Gelatina de } \\
\text { morango } \\
\text { Melão/ Mamão }\end{array}$ & $\begin{array}{l}\text { Flocos } \\
\text { Doce de leite com } \\
\text { queijo } \\
\text { Laranja/ Melancia }\end{array}$ & $\begin{array}{l}\text { Creme rosa } \\
\text { Pavê de Pêssego } \\
\text { Mamão/ Banana }\end{array}$ \\
\hline
\end{tabular}


Apêndice XII

CORAL - Serviços de Refeições Industriais Ltda PERÍODO: 22/07 à 26/07/02

\begin{tabular}{|c|c|c|c|c|c|}
\hline COMPOSIÇÃO & SEG - FEIRA & TER - FEIRA & QUAR - FEIRA & QUIN - FEIRA & SEX - FEIRA \\
\hline ENTRADA & $\begin{array}{l}\text { Salada Marcos } \\
\text { Alface/ Tomate } \\
\text { Chicória/ Vagem } \\
\text { Beterraba ralada } \\
\text { Abacaxi }\end{array}$ & $\begin{array}{l}\text { Salada Colorida } \\
\text { Alface/ Tomate } \\
\text { Acelga/ Broto de } \\
\text { feijão/ Abóbora } \\
\text { Mamão }\end{array}$ & \begin{tabular}{|l} 
Salada de \\
macarrão \\
Alface/ Tomate \\
Agrião/ Cenoura \\
coz. \\
Pepino/ Laranja
\end{tabular} & $\begin{array}{l}\text { Maionese básica } \\
\text { Alface/ Tomate } \\
\text { Almeirão/Abobrinha } \\
\text { Beterraba cozida } \\
\text { Melão }\end{array}$ & $\begin{array}{l}\text { Maionese } \\
\text { maravilha } \\
\text { Alface/ Tomate } \\
\text { Rúcula/ Ovos } \\
\text { cozidos } \\
\text { Cenoura cozida } \\
\text { Uva }\end{array}$ \\
\hline PRATOS PRINCIPAIS & $\begin{array}{l}\text { Frango chilindrón } \\
\text { Carne de sol } \\
\text { Picadinho cremoso }\end{array}$ & $\begin{array}{l}\text { Frango a la Kiev } \\
\text { Brochete misto } \\
\text { Língua ao molho } \\
\text { rotty }\end{array}$ & \begin{tabular}{|l|} 
Isca de lombo \\
Bife à rolê \\
Frango à caçadora \\
II
\end{tabular} & $\begin{array}{l}\text { Panqueca de } \\
\text { frango } \\
\text { Bife à Diana } \\
\text { Assado vienense }\end{array}$ & $\begin{array}{l}\text { Dobradinha } \\
\text { Frango Holândês } \\
\text { Peixe assado }\end{array}$ \\
\hline GUARNIÇÕES & $\begin{array}{l}\text { Bolo de batata } \\
\text { Legumes diversos }\end{array}$ & $\begin{array}{l}\text { Couve-flor ao forno } \\
\text { Rocambole de } \\
\text { espinafre com } \\
\text { queijo } \\
\end{array}$ & $\begin{array}{l}\text { Tomates recheados } \\
\text { Macarrão do Porto }\end{array}$ & $\begin{array}{l}\text { Croquete de milho } \\
\text { Suflê de Chuchu }\end{array}$ & $\begin{array}{l}\text { Couve refogada } \\
\text { Farofa simples }\end{array}$ \\
\hline ACOMPANHAMENTO & \begin{tabular}{|l} 
Arroz branco \\
Arroz boliviano \\
Feijão simples
\end{tabular} & $\begin{array}{l}\text { Arroz branco } \\
\text { Arroz integral } \\
\text { Feijão simples }\end{array}$ & $\begin{array}{l}\text { Arroz branco } \\
\text { Feijão simples } \\
\text { Tutu de feijão }\end{array}$ & $\begin{array}{l}\text { Arroz branco } \\
\text { Arroz integral } \\
\text { Feijão simples }\end{array}$ & $\begin{array}{l}\text { Arroz branco } \\
\text { Feijão simples } \\
\text { Feijão preto }\end{array}$ \\
\hline COMPLEMENTO & $\begin{array}{l}\text { Suco: Maracujá } \\
\text { Refresco: Goiaba } \\
\text { com acerola } \\
\end{array}$ & $\begin{array}{l}\text { Suco: Abacaxi } \\
\text { Refresco: Uva }\end{array}$ & $\begin{array}{l}\text { Suco: Melancia } \\
\text { Refresco: } \\
\text { Tangerina } \\
\end{array}$ & $\begin{array}{l}\text { Suco: Laranja } \\
\text { Refresco: } \\
\text { Tamarindo } \\
\end{array}$ & $\begin{array}{l}\text { Suco: Limão } \\
\text { Refresco: } \\
\text { Maracujá } \\
\end{array}$ \\
\hline SOBREMESA & $\begin{array}{l}\text { Doce de banana } \\
\text { Gelatina de uva } \\
\text { Mamão/ Melão }\end{array}$ & $\begin{array}{l}\text { Pudim de queijo } \\
\text { Flan de chocolate } \\
\text { com coco ralado } \\
\text { Melancia/ Laranja }\end{array}$ & $\begin{array}{l}\text { Gelatina de cereja } \\
\text { Delícia de pêssego } \\
\text { Melão/ Banana }\end{array}$ & $\begin{array}{l}\text { Doce de leite } \\
\text { cremoso } \\
\text { Pudim bicolor } \\
\text { Salada de frutas } \\
\text { Mamão }\end{array}$ & $\begin{array}{l}\text { Pavê de chocolate } \\
\text { Gelatina colorida } \\
\text { Melancia/ Abacaxi }\end{array}$ \\
\hline
\end{tabular}


Apêndice XIII

CORAL - Serviços de Refeições Industriais Ltda PERÍODO: 29/07 à 02/08/02

\begin{tabular}{|c|c|c|c|c|c|}
\hline COMPOSIÇÃO & SEG - FEIRA & TER - FEIRA & QUAR - FEIRA & QUIN - FEIRA & SEX - FEIRA \\
\hline ENTRADA & $\begin{array}{l}\text { Salada Nice } \\
\text { Alface/ Tomate } \\
\text { Agrião/ Cenoura } \\
\text { coz. } \\
\text { Chuchu/ Mamão } \\
\end{array}$ & $\begin{array}{l}\text { Torta fria } \\
\text { Alface/ Tomate } \\
\text { Acelga/ Pepino } \\
\text { Abóbora/ Melão }\end{array}$ & $\begin{array}{l}\text { Salada mista II } \\
\text { Alface/ Tomate } \\
\text { Tabule/ Mostarda } \\
\text { Beterraba cozida } \\
\text { Abacaxi } \\
\end{array}$ & $\begin{array}{l}\text { Salada Imperial } \\
\text { Alface/ Tomate } \\
\text { Abobrinha/ Rúcula } \\
\text { Cenoura cozida } \\
\text { Melancia } \\
\end{array}$ & $\begin{array}{l}\text { Salada Mimosa } \\
\text { Alface/ Tomate } \\
\text { Beterraba ralada } \\
\text { Espinafre/ Batata } \\
\text { doce/ Laranja } \\
\end{array}$ \\
\hline PRATOS PRINCIPAIS & $\begin{array}{l}\text { Frango à } \\
\text { passarinho } \\
\text { Bocadinho de } \\
\text { carne } \\
\text { Almôndegas } \\
\end{array}$ & $\begin{array}{l}\text { Strogonoff de frango } \\
\text { Escalopinho ao } \\
\text { molho madeira } \\
\text { Carne ao brasé }\end{array}$ & $\begin{array}{l}\text { CHURRASCO } \\
\text { Peixe à Itamaraty } \\
\text { Ovo frito }\end{array}$ & $\begin{array}{l}\text { Chester à } \\
\text { califórnia } \\
\text { Picadinho } \\
\text { especial } \\
\text { Bisteca grelhada }\end{array}$ & $\begin{array}{l}\text { Feijoada } \\
\text { Peixe à baiana } \\
\text { madalena }\end{array}$ \\
\hline GUARNIÇÕES & $\begin{array}{l}\text { Falso siri } \\
\text { Macarrão à } \\
\text { carbonana }\end{array}$ & $\begin{array}{l}\text { Batata corada } \\
\text { Creme de milho }\end{array}$ & $\begin{array}{l}\text { Cenoura e vagem } \\
\text { sautê } \\
\text { Pizza vegetariana }\end{array}$ & $\begin{array}{l}\text { Suflê de palmito } \\
\text { Quibebe de } \\
\text { mandioca }\end{array}$ & $\begin{array}{l}\text { Farofa simples } \\
\text { Couve à mineira }\end{array}$ \\
\hline ACOMPANHAMENTO & $\begin{array}{l}\text { Arroz branco } \\
\text { Arroz com brócolis } \\
\text { Feijão simples }\end{array}$ & $\begin{array}{l}\text { Arroz banco } \\
\text { Arroz Napolitano } \\
\text { Feijão simples }\end{array}$ & $\begin{array}{l}\text { Arroz branco } \\
\text { Arroz integral } \\
\text { Feijão simples }\end{array}$ & $\begin{array}{l}\text { Arroz branco } \\
\text { Arroz à grega } \\
\text { Feijão simples }\end{array}$ & $\begin{array}{l}\text { Arroz branco } \\
\text { Arroz integral } \\
\text { Feijão simples }\end{array}$ \\
\hline COMPLEMENTO & $\begin{array}{l}\text { Suco: Limão com } \\
\text { cenoura } \\
\text { Refresco: Goiaba } \\
\end{array}$ & $\begin{array}{l}\text { Suco: Laranja } \\
\text { Refresco: Uva }\end{array}$ & $\begin{array}{l}\text { Suco: Maracujá } \\
\text { Refresco: Caju }\end{array}$ & $\begin{array}{l}\text { Suco: Abacaxi c/ } \\
\text { hortelã } \\
\text { Refresco: Acerola }\end{array}$ & $\begin{array}{l}\text { Suco: Limão } \\
\text { Refresco: } \\
\text { Tangerina } \\
\end{array}$ \\
\hline SOBREMESA & $\begin{array}{l}\text { Delícia de pêssego } \\
\text { Gelatina de } \\
\text { Morango } \\
\text { Melancia/ Melão }\end{array}$ & $\begin{array}{l}\text { Bolo de cenoura cl } \\
\text { cobertura de } \\
\text { chocolate } \\
\text { Maravilha de limão } \\
\text { Mamão/ Banana }\end{array}$ & $\begin{array}{l}\text { Doce de leite } \\
\text { Pudim de biscoito } \\
\text { Laranja/ Melão }\end{array}$ & $\begin{array}{l}\text { Bolo quequel } \\
\text { Neve de laranja } \\
\text { Banana/ Mamão }\end{array}$ & $\begin{array}{l}\text { Flan de côco com } \\
\text { cobertura de } \\
\text { chocolate } \\
\text { Gelatina de uva } \\
\text { Melancia/ Abacax } \\
\end{array}$ \\
\hline
\end{tabular}


Apêndice XIV

CORAL - Serviços de Refeições Industriais Ltda PERÍODO: 05/08 à 09/08/02

\begin{tabular}{|c|c|c|c|c|c|}
\hline COMPOSIÇÃO & SEG - FEIRA & TER - FEIRA & QUAR - FEIRA & QUIN - FEIRA & SEX - FEIRA \\
\hline ENTRADA & $\begin{array}{l}\text { Salada Pabo } \\
\text { Alface/ Tomate } \\
\text { Acelga/ Repolho } \\
\text { Beterraba cozida } \\
\text { Mamão }\end{array}$ & $\begin{array}{l}\text { Salpicão de frango } \\
\text { Alface/ Tomate } \\
\text { Rúcula/ Cenoura } \\
\text { coz. } \\
\text { Abobrinha/ Laranja }\end{array}$ & $\begin{array}{l}\text { Salada dos Sonhos } \\
\text { Alface/ Tomate } \\
\text { Agrião/Beterraba } \\
\text { ral. } \\
\text { Vagem/ Melão }\end{array}$ & $\begin{array}{l}\text { Salada Ami } \\
\text { Alface/ Tomate } \\
\text { Chicória/ Berinjela } \\
\text { Chuchu/ Melancia }\end{array}$ & \begin{tabular}{|l|} 
Grão-de-bico \\
especial \\
Alface/ Tomate \\
Beterraba cozida \\
Rabanete/ Cenoura \\
ralada/ Laranja \\
\end{tabular} \\
\hline PRATOS PRINCIPAIS & $\begin{array}{l}\text { Frango Holandês } \\
\text { Cupim assado } \\
\text { Isca de carne } \\
\text { acebolada }\end{array}$ & $\begin{array}{l}\text { Strogonoff de carne } \\
\text { Bife Rossini } \\
\text { Frango à milanesa }\end{array}$ & $\begin{array}{l}\text { Isca de fígado } \\
\text { Vatapá de peixe } \\
\text { Frango na coca- } \\
\text { cola }\end{array}$ & $\begin{array}{l}\text { Lombo assado } \\
\text { com abacaxi } \\
\text { Frango grelhado } \\
\text { Bucadinho Bruce } \\
\text { Willis } \\
\end{array}$ & $\begin{array}{l}\text { Feijoada } \\
\text { Frango tropical } \\
\text { Peixe grelhado }\end{array}$ \\
\hline GUARNIÇÕES & $\begin{array}{l}\text { Nhoque ao sugo } \\
\text { Farofa de passas } \\
\text { com bacon }\end{array}$ & \begin{tabular}{|l|} 
Batata corada \\
Charuto \\
vegetariano \\
\end{tabular} & $\begin{array}{l}\text { Suflê de espinafre } \\
\text { e queijo } \\
\text { Banana frita }\end{array}$ & $\begin{array}{l}\text { Purê de mandioca } \\
\text { Macarrão ao sugo }\end{array}$ & $\begin{array}{l}\text { Couve à mineira } \\
\text { Farofa simples }\end{array}$ \\
\hline ACOMPANHAMENTO & $\begin{array}{l}\text { Arroz branco } \\
\text { Feijão simples } \\
\text { Feijão preto }\end{array}$ & $\begin{array}{l}\text { Arroz branco } \\
\text { Arroz Indiano } \\
\text { Feijão simples }\end{array}$ & $\begin{array}{l}\text { Arroz branco } \\
\text { Arroz integral } \\
\text { Feijão simples }\end{array}$ & \begin{tabular}{|l} 
Arroz branco \\
Arroz colorido \\
Feijão simples
\end{tabular} & $\begin{array}{l}\text { Arroz branco } \\
\text { Arroz integral } \\
\text { Feijão preto }\end{array}$ \\
\hline COMPLEMENTO & $\begin{array}{l}\text { Suco: Abacaxi } \\
\text { Refresco: } \\
\text { Tangerina } \\
\end{array}$ & $\begin{array}{l}\text { Suco: Maracujá } \\
\text { Refresco: Caju }\end{array}$ & $\begin{array}{l}\text { Suco: Limão } \\
\text { Refresco: Acerola }\end{array}$ & $\begin{array}{l}\text { Suco: Coquetel de } \\
\text { frutas } \\
\text { Refresco: Abacaxi } \\
\end{array}$ & $\begin{array}{l}\text { Suco: Limão } \\
\text { Refresco: Uva }\end{array}$ \\
\hline SOBREMESA & $\begin{array}{l}\text { Pêssego espelhado } \\
\text { Brigadeirão } \\
\text { Melão/ Banana }\end{array}$ & $\begin{array}{l}\text { Delícia de abacaxi } \\
\text { Banana } \\
\text { caramelada } \\
\text { Mamão/ Melancia }\end{array}$ & $\begin{array}{l}\text { Gelatina de } \\
\text { framboesa } \\
\text { Creme xadrez } \\
\text { Abacaxi } \\
\text { Salada de frutas }\end{array}$ & $\begin{array}{l}\text { Pudim de leite } \\
\text { Creme de côco } \\
\text { Melão/ Banana }\end{array}$ & $\begin{array}{l}\text { Flan de morango } \\
\text { com cereja } \\
\text { Gelatina de } \\
\text { morango } \\
\text { Melancia/ Mamão }\end{array}$ \\
\hline
\end{tabular}


Apêndice XV

CORAL - Serviços de Refeições Industriais Ltda PERÍODO: 12/08 à16/08/02

\begin{tabular}{|c|c|c|c|c|c|}
\hline COMPOSIÇÃO & SEG - FEIRA & TER - FEIRA & QUAR - FEIRA & QUIN - FEIRA & SEX - FEIRA \\
\hline ENTRADA & $\begin{array}{l}\text { Salada Samira } \\
\text { Alface/ Tomate } \\
\text { Espinafre/ } \\
\text { Beterraba ralada } \\
\text { /Abobrinha } \\
\text { Uva }\end{array}$ & $\begin{array}{l}\text { Salada Suíça } \\
\text { Alface/ Tomate } \\
\text { Acelga/ Tabule } \\
\text { Vagem/ Melancia }\end{array}$ & $\begin{array}{l}\text { Salada de } \\
\text { Cenouras } \\
\text { Alface/ Tomate } \\
\text { Agrião/ Beterraba } \\
\text { cozida } \\
\text { Maxixe/ Abacaxi }\end{array}$ & $\begin{array}{l}\text { Salada Waldorf } \\
\text { Alface/ Tomate } \\
\text { Cenoura ralada } \\
\text { Repolho } \\
\text { /Abobrinha } \\
\text { Mamão }\end{array}$ & $\begin{array}{l}\text { Salada Russa } \\
\text { Alface/ Tomate } \\
\text { Beterraba cozida } \\
\text { Pepino/ Chuchu } \\
\text { Laranja }\end{array}$ \\
\hline PRATOS PRINCIPAIS & $\begin{array}{l}\text { Frango na laranja } \\
\text { Carne com batata } \\
\text { baroa } \\
\text { Escalopinho ao } \\
\text { molho madeira }\end{array}$ & $\begin{array}{l}\text { Frango grelhado } \\
\text { Bife rolê } \\
\text { Lagarto recheado } \\
\text { com linguiça }\end{array}$ & $\begin{array}{l}\text { CHURRASCO } \\
\text { Peixe ao molho de } \\
\text { camarão } \\
\text { Omelete de queijo } \\
\text { e presunto }\end{array}$ & $\begin{array}{l}\text { Fricassé de } \\
\text { frango } \\
\text { Pernil agridoce } \\
\text { Carne moída com } \\
\text { azeitona }\end{array}$ & $\begin{array}{l}\text { Feijoada } \\
\text { Peixe à Dorê } \\
\text { Frango Holandês }\end{array}$ \\
\hline GUARNIÇÕES & $\begin{array}{l}\text { Creme de milho } \\
\text { Berinjela recheada }\end{array}$ & $\begin{array}{l}\text { Purê Argentino } \\
\text { Farofa de passas }\end{array}$ & $\begin{array}{l}\text { Batata Portuguesa } \\
\text { Bolinho de aipim } \\
\text { recheado }\end{array}$ & $\begin{array}{l}\text { Espaguete à } \\
\text { Francesa } \\
\text { Legumes verdes }\end{array}$ & $\begin{array}{l}\text { Couve à mineira } \\
\text { Farofa simples }\end{array}$ \\
\hline ACOMPANHAMENTO & $\begin{array}{l}\text { Arroz branco } \\
\text { Arroz à Princesa } \\
\text { Feijão simples }\end{array}$ & $\begin{array}{l}\text { Arroz branco } \\
\text { Arroz integral } \\
\text { Feijão simples }\end{array}$ & \begin{tabular}{|l|} 
Arroz branco \\
Feijão simples \\
Feijão Tropeiro
\end{tabular} & $\begin{array}{l}\text { Arroz branco } \\
\text { Arroz integral } \\
\text { Feijão simples }\end{array}$ & $\begin{array}{l}\text { Arroz branco } \\
\text { Arroz Indiano } \\
\text { Feijão simples }\end{array}$ \\
\hline COMPLEMENTO & $\begin{array}{l}\text { Suco: Maracujá } \\
\text { Refresco: Uva }\end{array}$ & $\begin{array}{l}\text { Suco: Abacaxi } \\
\text { Refresco: } \\
\text { Tamarindo }\end{array}$ & $\begin{array}{l}\text { Suco: Coquetel de } \\
\text { frutas } \\
\text { Refresco: Acerola }\end{array}$ & $\begin{array}{l}\text { Suco: Melancia } \\
\text { Refresco: Caju }\end{array}$ & $\begin{array}{l}\text { Suco: Limão } \\
\text { Refresco: } \\
\text { Tangerina }\end{array}$ \\
\hline SOBREMESA & $\begin{array}{l}\text { Pudim bicolor } \\
\text { Creme de ameixa } \\
\text { Abacaxi/ Mamão }\end{array}$ & $\begin{array}{l}\text { Curau } \\
\text { Manjar com ameixa } \\
\text { Melão/ Laranja }\end{array}$ & $\begin{array}{l}\text { Gelatina colorida } \\
\text { Pavê simples } \\
\text { Banana/ Melancia }\end{array}$ & $\begin{array}{l}\text { Bolo de chocolate } \\
\text { Pêssego ao } \\
\text { creme de baunilha } \\
\text { Abacaxi/ Laranja }\end{array}$ & $\begin{array}{l}\text { Gelatina de } \\
\text { morango } \\
\text { Pudim de maracujá } \\
\text { Mamão/ Melancia } \\
\end{array}$ \\
\hline
\end{tabular}


Apêndice XVI

CORAL - Serviços de Refeições Industriais Ltda PERÍODO: 19/08 à 23/08/02

\begin{tabular}{|c|c|c|c|c|c|}
\hline COMPOSIÇÃO & SEG - FEIRA & TER - FEIRA & QUAR - FEIRA & QUIN - FEIRA & SEX - FEIRA \\
\hline ENTRADA & $\begin{array}{l}\text { Salada Camponesa } \\
\text { Alface/ Tomate } \\
\text { Lentilha/ Abóbora } \\
\text { Acelga/ Mamão }\end{array}$ & $\begin{array}{l}\text { Salada Original } \\
\text { Alface/ Tomate } \\
\text { Chicória/ Cenoura } \\
\text { coz./ Abobrinha } \\
\text { Melão }\end{array}$ & $\begin{array}{l}\text { Salada Siciliana } \\
\text { Alface/ Tomate } \\
\text { Chuchu/ Agrião } \\
\text { Beterraba cozida } \\
\text { Melancia }\end{array}$ & $\begin{array}{l}\text { Salada Marília } \\
\text { Alface/ Tomate } \\
\text { Rúcula/ broto de } \\
\text { feijão/ Cenoura } \\
\text { ral. Abacaxi }\end{array}$ & $\begin{array}{l}\text { Taça de legumes } \\
\text { Alface/ Tomate } \\
\text { Mostarda/ } \\
\text { Beterraba coz./ } \\
\text { Feijão fradinho ao } \\
\text { vinagrete } \\
\text { Laranja }\end{array}$ \\
\hline PRATOS PRINCIPAIS & $\begin{array}{l}\text { Frango à romana } \\
\text { Fricandole de carne } \\
\text { Cozido com } \\
\text { legumes }\end{array}$ & $\begin{array}{l}\text { Frango ao molho } \\
\text { de açafrão } \\
\text { Guisado à } \\
\text { Espanhola } \\
\text { Isca de lombo à } \\
\text { campanha } \\
\end{array}$ & $\begin{array}{l}\text { Frango Royal } \\
\text { Peixe assado } \\
\text { Tornedor ao molho } \\
\text { Rotty }\end{array}$ & \begin{tabular}{|l} 
Bife acebolado \\
Frango surpresa \\
Almôndegas \\
recheadas
\end{tabular} & $\begin{array}{l}\text { Rabada com agrião } \\
\text { Peixe à dorê } \\
\text { Frango à chilindrón }\end{array}$ \\
\hline GUARNIÇÕES & $\begin{array}{l}\text { Lasanha de milho } \\
\text { Couve-flor à dorê }\end{array}$ & $\begin{array}{l}\text { Quiabo refogado } \\
\text { Farofa de ovo }\end{array}$ & $\begin{array}{l}\text { Pirão de peixe } \\
\text { Macarrão alho e } \\
\text { óleo }\end{array}$ & $\begin{array}{l}\text { Mandioca cozida } \\
\text { Suflê de chuchu }\end{array}$ & $\begin{array}{l}\text { Polenta } \\
\text { Farofa simples }\end{array}$ \\
\hline ACOMPANHAMENTO & $\begin{array}{l}\text { Arroz branco } \\
\text { Arroz à grega } \\
\text { Feijão simples }\end{array}$ & $\begin{array}{l}\text { Arroz branco } \\
\text { Arroz integral } \\
\text { Feijão simples }\end{array}$ & $\begin{array}{l}\text { Arroz branco } \\
\text { Arroz Indiano } \\
\text { Feijão simples }\end{array}$ & $\begin{array}{l}\text { Arroz branco } \\
\text { Arroz integral } \\
\text { Feijão simples }\end{array}$ & $\begin{array}{l}\text { Arroz branco } \\
\text { Feijão simples } \\
\text { Feijão preto }\end{array}$ \\
\hline COMPLEMENTO & $\begin{array}{l}\text { Suco: Maracujá } \\
\text { Refresco: Caju }\end{array}$ & $\begin{array}{l}\text { Suco: Laranja } \\
\text { Refresco: Goiaba }\end{array}$ & $\begin{array}{l}\text { Suco: Abacaxi } \\
\text { Refresco: } \\
\text { Tangerina } \\
\text { c/ mamão } \\
\end{array}$ & $\begin{array}{l}\text { Suco: Melancia } \\
\text { Refresco: Laranja }\end{array}$ & $\begin{array}{l}\text { Suco: Limão } \\
\text { Refresco: Uva }\end{array}$ \\
\hline SOBREMESA & $\begin{array}{l}\text { Gelatina de limão } \\
\text { Arroz doce } \\
\text { Melancia/ Laranja }\end{array}$ & $\begin{array}{l}\text { Danete } \\
\text { Flan de côco } \\
\text { Abacaxi/ Mamão }\end{array}$ & $\begin{array}{l}\text { Pudim de chocolate } \\
\text { Rocombole de } \\
\text { doce de leite c/ } \\
\text { ameixa } \\
\text { Laranja/ Melão } \\
\end{array}$ & $\begin{array}{l}\text { Creme xadrez } \\
\text { Banana } \\
\text { caramelada } \\
\text { Salada de frutas } \\
\text { Mamão }\end{array}$ & $\begin{array}{l}\text { Mané pelado } \\
\text { Gelatina fantasia } \\
\text { Banana/ Melancia }\end{array}$ \\
\hline
\end{tabular}




\section{Referências Bibliográficas}

ANTUNES, L. M. G. \& ARAÚJO, M.C.P. Mutagenicidade e antimutagenicidade dos principais corantes para alimentos. Rev. Nut.. Campinas, 2000.

ARAÚJO, Júlio M. A. Química de alimentos: teoria e prática. Viçosa: UFV, Impr. Univ., 1995.

BAILEY, G. S, WILLIAMS, D. E. Food Technol, 1993.

BERNARDES, S.M. Redescobrindo os alimentos. São Paulo: Loyola, 1997.

BRANDS et al. Mutagenicity of heated sugar-casein systems: effect of the Maillard reaction. Journal -of- Agricultura I- and - Food - Chemistry, 2000.

BRASIL. Portaria n 36, publicada no Diário Oficial da União em 19 de Janeiro de 1990.

BRASIL. Resolução n 104, da Agência Nacional de Vigilância Sanitária de 14 de Maio de 1993.

BRUNE, et al. Iron absorption from bread in humans: inhibiting effects of cereal fiber, phytate and inositol phosphates with different. Nutr. , 1992. 
CAMARGO, M.C.R. Avaliação da ingestão de hidrocarbonetos policíclicos aromáticos através da dieta. Campinas. Tese de Doutorado. Faculdade de Engenharia de Alimentos, Universidade Estadual de Campinas UNICAMP, 2001.

CAMARGO, M.S.F. O \& TOLEDO, M.C.F. Hidrocarbonetos aromáticos policíclicos em margarina, cremes vegetais e maionese. Ciênc. Tecnol. Aliment.,2000.

CAMARGO, M.S.F.O. TOLEDO, M.C.F. Efeito do processamento na combinação de óleo refinado de milho por benzo(a)pireno. Brazilian Journal of Food Technology, 1998.

CHEFTEL,J.C, CHEFTEL,H. Introducción a la bioquimica y tecnologia de los alimentos. Acribia, Zaragoza,1998.

CHIANG, T. A. et al. Mutagenicity and aromatic amine content of fumes from heated cooking oils produced in Taiwan. Food Chem Toxicol, 1999.

DIAS, L. C. G. D.; CAMARGO, J.L.V.; RODRIGUES, M.A.M. Dieta e câncer. Departamento de Patologia da Faculdade de Medicina de Botucatu - UNESP, 1991.

DUARTE, M. \& MIDIO, A. F. Nitratos e nitritos em alimentos. Cadernos de Nutrição, 1996.

ESCUDEIRO, P. Alimentação. Rio de Janeiro. Scientifica, 1934. 
FERRARI, Carlos Kusano Bucalen. Oxidação lipídica em alimentos e sistemas biológicos: Mecanismos gerais e implicações nutricionais e patológicas. Revista Nutrição: Campinas, 1998.

IARC. Monographs on the Evaluation of Carcinogenic Risk to Humans. Vol. 56. Some Naturally Occurring Aromatic Amines and Mycotoxins. Internacional Agency for Research on Cancer. Lyon, 1993.

JARIWALLA, R. J. Anticancer effects of phytate. Am J Clin Nutr, 1992.

KNIZE,M.G, SALMON,C.P, MEHTA,S.S, FELTON,J.S. Mutation res.1997

LARKESSON et al. Effects of frying and storage on cholesterol oxidation em minced meat products. Journal - of - the - American - Oi I- Chimists'-Society, 2000.

LARSSON, B.K., SAHLBERG, G. Polycyclic aromatic hudrocarbons in lettuce: influence of a highway and an aluminium smelter. In: Sixth International Symposium on Physical and Biological Chemestry, Columbus, 1981.

MARKO et al. Studies on the inhibition of tumour cell growth and microtubule assemblyby 3-hydroxy-4-((E)-(2-furyl) methylidene) methyl-3-cyclopentene-1,2dione, an intensively coloured Maillard reaction product. Food-and-ChemicalToxicology,2002.

MESSINA, M. Phytate's potential role in reducing colon-cancer risk. Am. J. Clin. Nutr, 1991. 
MIDIO, A.F. \& MARTINS, D. I. Toxicologia de alimentos. São Paulo, Livraria Varela, 2000.

SAVARIN, B. A fisiologia do gosto. São Paulo, Companhia das Letras, 1995.

SGARBIERI, V. C. Alimentação e nutrição. Campinas UNICAMP. Almed,1997.

SGARBIERI, V. C. Proteínas em alimentos protéicos: propriedades, degradação, modificação. São Paulo, Varela, 1996.

SICHIERI, R.; EVERHART, J.E.; and MENDONÇA, G. A. S. Diet and mortality from common cancers in Brazil: an ecological study. Caderno de Saúde Pública, 1996.

SILVA, M. R. \& SILVA M. A. A. P. Aspectos nutricionais de fitatos e taninos. Revista Nutrição, Campinas, 1999.

SILVA, S.M.C.S. \& BERNADES, S.M. CARDÁPIO: Guia prático para a elaboração. São Paulo: Atheneu/Centro Universitário São Camilo, 2001.

SKOG et al. Effect of cooking temperature on the formation of heterocyclic amines in fried meat products and pan residues. Carcinogenesis,1995.

TEICHMANN, I. CARDÁPIOS técnicas e criatividade. 5 ed. Caxias do Sul, EDUCS, 2000. 
TORRES, E. A. F. da Silva \& MACHADO, F. M. S. Alimentos em questão: uma abordagem técnica para as dúvidas mais comuns. São Paulo: Ponto Crítico, 2001.

VASCONCELLOS, F.; CAVALCANTI, E.; BARBOSA, L. MENU: como montar um cardápio eficiente. São Paulo, ROCA, 2002. 